\title{
Strategies for pest control in sorghum in India
}

\author{
H. C. SHARMA \\ International Crops Research Institute for the Semi-Arid Tropics (ICRISAT) \\ Patancheru, P.O. 502 324, A.P. India
}

\begin{abstract}
Host-plant resistance in conjunction with natural enemies and cultural practices should form the backbone of future pest control programmes. Sources of resistance to Atherigona soccata Rond., Chilo partellus Swin. and Contarinia sorghicola Coq. have been identified. Efforts should be made to incorporate resistance into plants with good agronomic background and to strengthen the level of resistance. Resistance to pests and grain yield should be given equal consideration in the development and release of new cultivars. Cultivars with loose panicles may be developed for areas endemic to head bugs and head caterpillars. Pest avoidance through timely planting as decided by pest-population dynamics and rainfall patterns, balanced fertilizer application, clean cultivation, and proper crop combinations should be popularized among the farmers to reduce crop losses. Readily available and inexpensive insecticides may be used as and when necessary based on economic thresholds.
\end{abstract}

\section{Introduction}

Sorghum is the third most important cereal crop in India after rice and wheat. Grain yields on peasant farms are generally low $(500-800 \mathrm{~kg} / \mathrm{ha})$ mainly because of insect pest damage. Nearly $12 \%$ of the actual crop produce is lost because of insect pests (NCEAR, 1967), and earhead pests alone cause a minimum annual crop loss valued at Rs.972 million (Leuschner and Sharma, 1983).

Nearly 150 insect species have been reported as pests on sorghum (Reddy and Davies, 1979; Jotwani et al., 1980) of which 31 are of potential economic importance (Table 1). Shoot fly, Atherigona soccata Rond, stem borer, Chilo partellus Swin., armyworm, Mythimna separata Wik., midge, Contarinia sorghicola Coq., headbug, Calocoris angustatus Leth., and head caterpillars, Heliothis armigera Hb., Eublema spp. and Cryptoblabes spp., can be considered the major pests in India. This paper summarizes current knowiedge on various pest control components and formulates a future strategy for pest control in sorghum in India.

\section{Current pest control recommendations and their use in farmer's fields}

Most farmers consider pest control unnecessary until the damage becomes visible and threatens to reduce crop. yields substantially. A number of pest control recommendations involving cultural practices, insecticides, and in some cases resistant varieties have been developed. Our experience shows that farmers pay little attention to pest control on sorghum and many other crops in the semi-arid regions. The farmers' pest control operations rarely go beyond adopting various cultural practices, growing less susceptible traditional cultivars, and occasionally dusting or spraying with readily-available cheap insecticides. The main factors that seem to restrict the adoption of effective pest control measures are low cost-benefit ratios, nonavailability of inputs such as fertilizers and pesticides, and ignorance of the potential benefits of pest control.

In traditional farming systems, farmers may adopt such pest management practices as optimum sowing dates, high seeding rate, weeding, interculture, mixed cropping, and crop rotations. However, they are unlikely to adopt modern pest control practices until production levels justify the extra input involved.

\section{Pest control components in the sorghum agro-ecosystems}

\section{Cultural practices}

A number of crop husbandry practices which directly or indirectly help reduce pest damage have become an integral component of farming systems. The need for ecologically sound, effective, and economic methods for pest control has prompted renewed interest in cultural methods. The merit of many of these traditional farm practices has been confirmed by learning why farmers do what they do, but some practices still remain to be thoroughly investigated and understood. Cultural "practices to suppress pest populations are best suited for sorghum growing regions because: (1) they have become an integral component of crop-husbandry practices; (2) they involve no additional costs and (3) they do not disturb natural enemies of the pests concerned.

Tillage. Ploughing after harvest and before planting reduces the numbers and carryover of such insects as white grubs, Holotrichia sp., grasshoppers, Hieroglyphus banian Fab., $H$. nigrorepletus Bol., Colemania sphenerioides Bol, hairy caterpillar, Amsacta moorei Butl., and stem borer, $C$. partellus Swin., by exposing them to parasites, predators, and such adverse weather factors as high temperatures and low relative humidity (Gahukar and Jotwani, 1980).

Fertilizer and nutrient balance. The extent and nature of fertilizer application influences the susceptibility of the crop to insects. During the 1983 rainy season, unfertilized plots of CSH 1 at ICRISAT Center suffered heavy shoot fly damáge compared with fertilized plots. Nitrogenous fertilizers are reported to decrease $A$. soccata Rond. incidence in sorghum (Reddy and Narashimarao, 1975; Chand et al., 1979) possibly by increasing plant vigour. However, Kundu 
Table 1. Insect and mite pests of sorghum

\begin{tabular}{|c|c|c|c|c|}
\hline Common name & Scientific $n$ & & Nature of damage & Pest status \\
\hline \multicolumn{5}{|l|}{ SOIL PESTS } \\
\hline White grub & Anomala polita Blanch. & (Coleoptera: Melonthidae) & Feed on roots & Minor \\
\hline White grub & Holotrichia consanguinea Blanch. & (Coleoptera: Melonthidae) & Feed on roots & Minor \\
\hline False wireworm & Gonocephalum dorsogranosum Frm. & (Coleoptera: Tenebrionidae) & $\begin{array}{l}\text { Feed on germinating seeds, } \\
\text { seedlings and roots }\end{array}$ & Minor \\
\hline False wireworm & Gonocephalum vagum Stev. & (Coleoptera: Tenebrionidae) & $\begin{array}{l}\text { Feed on germinating seeds, } \\
\text { seedlings, and roots }\end{array}$ & Minor \\
\hline \multicolumn{5}{|l|}{ SEEDLING PESTS } \\
\hline Flea beetle & Chaetocnema sp. & (Coleoptera: Curculionidae) & Feed on leaves & Minor . \\
\hline Flea beetle & Phyllotreta chotanica Duv. & (Coleoptera: Curculionidae) & Feed on leaves & Minor \\
\hline Shoot fly & Atherigona soccata Rond. & (Muscidae: Diptera) & $\begin{array}{l}\text { Feed on the growing point } \\
\text { and produce a deadheart }\end{array}$ & Major \\
\hline Pink stem borer & Sesamia inferens Walk. & (Noctuidae: Lepidoptera) & $\begin{array}{l}\text { Larvae feed on leaves and } \\
\text { stem producing shot holes, } \\
\text { deadheart, and later stem- } \\
\text { tunnelling }\end{array}$ & $\begin{array}{l}\text { Major } \\
\text { More serious on } \\
\text { the post-rainy } \\
\text { season crop }\end{array}$ \\
\hline Spotted stem borer & Chilo partellus Swin. & (Pyralidae: Lepidoptera) & $\begin{array}{l}\text { Larvae feed on leaves and } \\
\text { stem producing shot holes, } \\
\text { deadheart and later stem- } \\
\text { tunnelling }\end{array}$ & $\begin{array}{l}\text { Major } \\
\text { More serious on } \\
\text { fodder sorghum in } \\
\text { North India and } \\
\text { occasionally on the } \\
\text { main crop in South } \\
\text { India }\end{array}$ \\
\hline \multicolumn{5}{|l|}{ FOLIAGE PESTS } \\
\hline Grey weevil & Myllocerus spp. & (Curculionidae: Coleoptera) & Feed on leaves & Minor \\
\hline Maize aphid & Rhopalosiphum maidis Fitch. & (Aphididae: Hemiptera) & $\begin{array}{l}\text { Sucks sap from the whorl } \\
\text { leaves and the earhead }\end{array}$ & $\begin{array}{l}\text { Minor. Occasionally } \\
\text { serious }\end{array}$ \\
\hline Shoot bug & Peregrinus maidis Ashm. & (Delphacidae: Hemiptera) & $\begin{array}{l}\text { Sucks sap from the whor } \\
\text { leaves and the earhead }\end{array}$ & $\begin{array}{l}\text { Minor. Becomes } \\
\text { serious during } \\
\text { dry periods, and } \\
\text { particularly so on } \\
\text { the rabi crop }\end{array}$ \\
\hline Red hairy caterpillar & Amsacta moorei Butl. & (Arctiidae: Lepidoptera) & Feed on leaves & Minor \\
\hline Armyworm & Mythimna separata Walk. & (Noctuidae: Lepidoptera) & Feed on leaves & Major \\
\hline Leaf folder & Marasmia suspicalis WIk. & (Pyralidae: Lepidoptera) & $\begin{array}{l}\text { Fold the leaves and feed } \\
\text { inside on the green pratter }\end{array}$ & $\begin{array}{l}\text { Minor. Occasionally } \\
\text { becomes serious }\end{array}$ \\
\hline Leat folder & Marasmia trapezalis Gue. & (Pyralidae: Lepidoptera) & $\begin{array}{l}\text { Fold the leaves and feed } \\
\text { inside on the green matter }\end{array}$ & $\begin{array}{l}\text { Minor. Occasionally } \\
\text { becomes serious }\end{array}$ \\
\hline $\begin{array}{l}\text { Deccan wingless } \\
\text { grasshopper }\end{array}$ & Colemania sphenerioides Bal. & (Acridiidae: Orthoptera) & $\begin{array}{l}\text { Feed on leaves and the } \\
\text { mi!ky grain }\end{array}$ & Minor \\
\hline Paddy grasshopper & Hieroglyphys banian Fab. . . . & (Acridiidae: Orthoptera) & $\begin{array}{l}\text { Feed on leaves and the } \\
\text { milky grain }\end{array}$ & Minor \\
\hline Paddy grasshopper & Hieroglyphus nigrorepletus Bol. & (Acridiidae: Orthoptera) & $\begin{array}{l}\text { Feed on leaves and the } \\
\text { milky grain }\end{array}$ & Minor \\
\hline Mite & Oligonychus indicus Hirst. & (Acarina: Tetranychidae) & $\begin{array}{l}\text { Sucks sap from the } \\
\text { leaves }\end{array}$ & $\begin{array}{l}\text { Minor. Becomes serious } \\
\text { during dry periods } \\
\text { assuming the status of } \\
\text { a regular pest }\end{array}$ \\
\hline \multicolumn{5}{|l|}{ EARHEAD PESTS } \\
\hline Blister beetle & Cylindrothorax tenuicollis Pall: & (Coleoptera: Meloidae) & Feed on infiorescens & Minor \\
\hline Blister beetle & Mylabris pustulata Thunb. & (Coleoptera: Meloidae) & Feed on infiorescens : & Minor \\
\hline Midge fly & Contarinia sorghicola Coq. & (Cecidomyiidae: Diptera) & $\begin{array}{l}\text { Feed on the developing } \\
\text { ovary }\end{array}$ & Major \\
\hline Headbug & Calocoris angustatus Leth. " & (Miridae: Hemiptera) & $\begin{array}{l}\text { Sucks sap from the } \\
\text { developing grain }\end{array}$ & Major \\
\hline Painted bug & Bagrada cruciferarum Kirk. & (Pentatomidae: Hemiptera) & Sucks sap & $\begin{array}{l}\text { Minor. Occasionally } \\
\text { becomes serious }\end{array}$ \\
\hline Red cotton bug & Dysdercus koenigi Fab. & (Pyrrhocoridae: Hemiptera) & Sucks sap & $\begin{array}{c}\text { Minor. Occasionally } \\
\text { becomes serious }\end{array}$ \\
\hline Head caterpillar & Celama analis W. and W. & (Noctuidae: Lepidoptera) & Feed on developing grain & $\begin{array}{c}\text { Minor. Occasionally } \\
\text { becomes serious }\end{array}$ \\
\hline Head caterpillar & Eublema silicula Swin. & (Noctuidae: Lepidoptera) & Feed on developing grain & $\begin{array}{l}\text { Mirior. Occasionatly } \\
\text { becomes serious }\end{array}$ \\
\hline Head caterpillar & Heliothis armigera Swin. & (Noctuidae: Lepidoptera) & Feed on developing grain & $\begin{array}{l}\text { Major. Becoming } \\
\text { serious on compact } \\
\text { headed genotypes }\end{array}$ \\
\hline Head caterpillar & Cryptoblabes gnidiella Mill. & (Pyralidae: Lepidoptera) & Feed on developing grain & Minor \\
\hline Thrips & Hapiothrips ganglebaueri Sch. & (Thripidae: Thysanoptera) & Feed on developing grain & Minor \\
\hline
\end{tabular}


et al. (1978) observed no effect of nitrogenous fertilizers on shoot fly damage. Channabasavanna et al. (1969) reported a decrease in shoot fly damage after the application of phosphatic fertilizers, but Venugopal et al. (1977a) and Rajashekhara et al. (1973) found no such evidence. Nitrogenous fertilizers also decrease $C$. partellus damage (Lakshminarayana and Subba Rao, 1975). These differences in fertilizer response may be due to genotypic variation. Shoot fly damage is also affected by the influence of herbicides on plant growth (L. R. Housse, 1984, personal communication).

Soil moisture. Soil moisture influences crop damage through its effect on plant vigour and growth. Plants growing under drought stress suffer higher damage from A. soccata, C. partellus and $P$. maidis Ashm. In rainfed agriculture, however, there is little scope for manipulating soil moisture content except by moisture-conserving practices and irrigation.

Time of sowing. Sowing time considerably influences the extent of insect damage. Normally, farmers plant sorghum with the first good monsoon showers. Synchronous sowing of cultivars in similar maturity groups over large areas in a short span of time helps reduce yield losses caused by shoot fly (Jotwani et al., 1970; Thimmaiah et al., 1973b; Ramnath et al., 1974), midge (Hardas et al., 1972; Jotwani et al., 1972b), and head bug (Thimmaiah et al.,.. 1972). In Tamil Nadu there is an old adage among farmers "Inform your neighbour before you plant sorghum lest his crop be destroyed by shoot fly and headbugs.".

Plant density. The traditional practice of using a high séeding rate helps to maintain optimum plant stands and reduce $A$. soccata damage (Gahukar and Jotwani, 1980). During the 1981-82 post-rainy season at ICRISAT Center, plots of CSH 5 thinned 30 days after emergence, suffered less shoot fly infestation than plots thinned 10 days after emergence. Shoot fly damage is higher when plant populations are low (Davies and Reddy, 1981).

Interculture. During interculture, the pupae of $A$. soccata and $M$. separata, and larvae of Holotrichia sp., Gonocephalum spp., $M$. separata etc., are exposed to parasites, predators, and other adverse environmental factors.

Weeding. Timely weeding helps reduce damage from some insects. Many common weeds act as hosts for oviposition, provide better ecological niches, and places for insects to hide, thus shielding them from natural enemies and insecticide sprays. Crops that are free from weeds suffer lower armyworm damage than weed-infested crops (Sharma et al., 1982).

Field sanitation. Collecting and burning stubble and chaffy earheads reduces the carryover of $C$. partellus and C. sorghicola. Stalks from the previous season should be fed to cattle or burnt before the onset of monsoon rains to reduce the carryover of stem borer (Gahukar and Jotwani, 1980).
Fallowing and close season. Fallowing reduces the carryover and build up of pest populations from one season to the next. Strict observance of a closed season during summer can possibly reduce the carryover of $A$. soccata and $C$. angustatus.

Crop rotation. Crop rotation is another means of reducing pest infestation. It breaks the continuity of the food chain of oligophagus pests. Sorghum is generally rotated with cotton, groundnut or sugarcane. This may halt any increase in the populations of $A$. soccata, $C$. sorghicola and $C$. angustatus.

Cropping systems. A carefully-selected cropping system (intercropping or mixed cropping) can help reduce pest incidence or minimize the. risks involved in monocultures. Sorghum is generally intercropped with pigeonpea, cotton, cowpea, safflower or other pulses. Atherigona soccata and $C$. sorghicola damage is reduced when sorghum is intercropped with leguminous crops (Hardas et al., 1980).

\section{Biological control}

In sorghum, the scope for total biological control appears limited because the cropping period is short and there is no crop continuity to sustain the natural enemies and their hosts. Natural enemies of important pests of sorghum are listed in Table 2. Future attention should focus on: identifying natural enemies and studying their activity periods, efficiency, and usefulness, and studying farming systems, crop combinations, and crop cultivars that encourage the activity of natural enemies.

\section{Host-plant resistance}

The best plant protection for the future should be one based on host-plant resistance (Frankel and Bennet, 1970). This method is particularly relevant to subsistence farming systems of the semi-arid tropics. Breeding for pest resistance has received little attention in the past, but now the importance of breeding not only for yield, but for quality; adaptability, and pest resistance is being increasingly recognized. According to Blum (1972) plant breeders, in general, appear to lack an understanding of insects and their hosts and tend to regard the insect populations as a fixed environmental parameter, with all the consequent. implications. The release of superior but otherwise susceptible crop varieties in the tropics will not achieve real yield potential (Pradhan, 1973). However, cultivars that help increase crop yields (e.g. $\mathrm{CSH}$ 1) but change the pest complex should be watched carefully and the newer pest problems countered effectively until cultivars. with adequate levels of resistance are developed (L. R. House, 1984, personal communication).

Plant resistance as a method of pest control offers many advantages in sorghum growing regions; for some insect species it is the only way of effective pest control. The most attractive feature of using resistant cultivars is that virtualiy no skill in pest control application techniques or cash investment is involved. But resistant cultivars are not a panacea for all pest problems (Painter, 1951). They are 


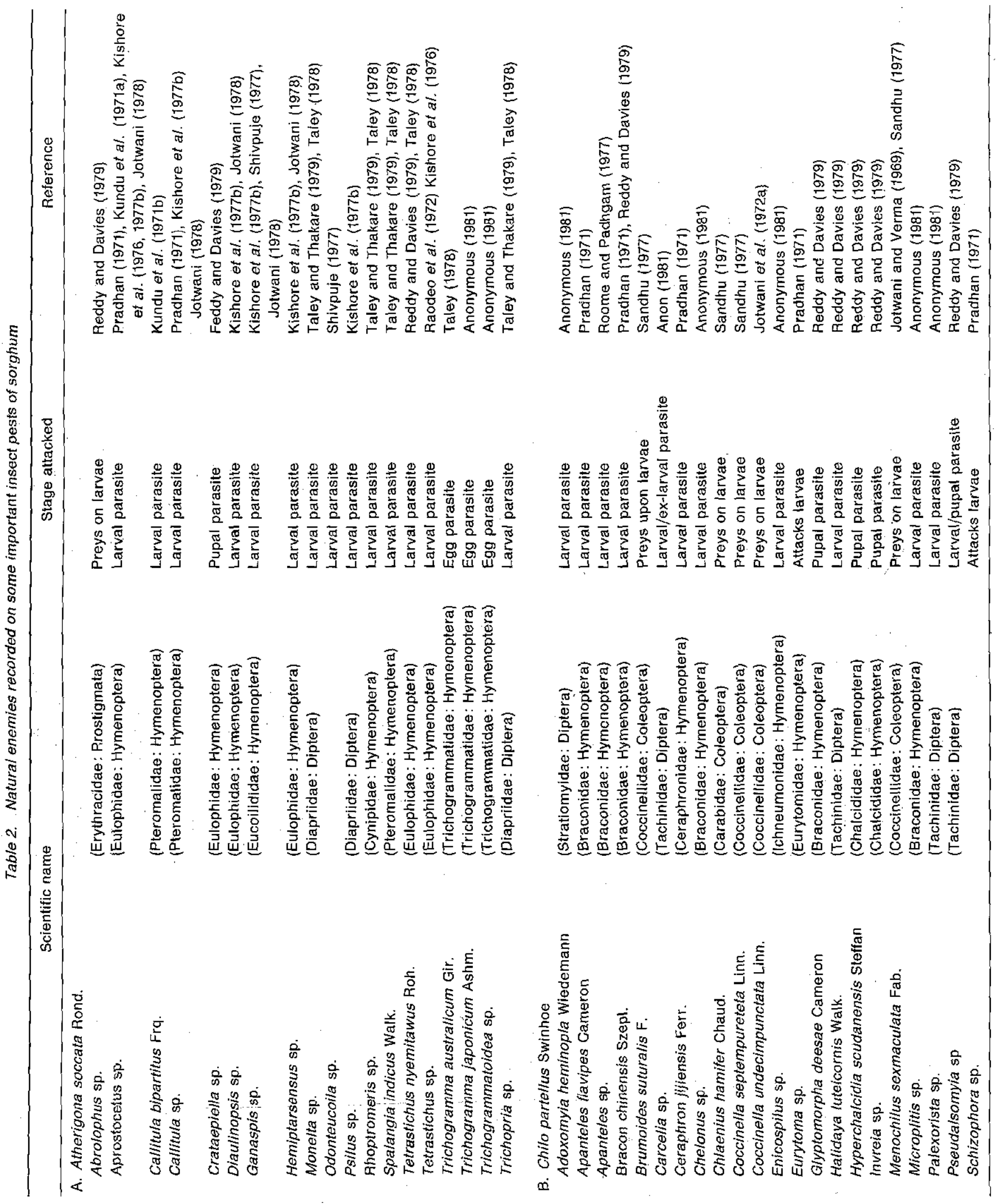




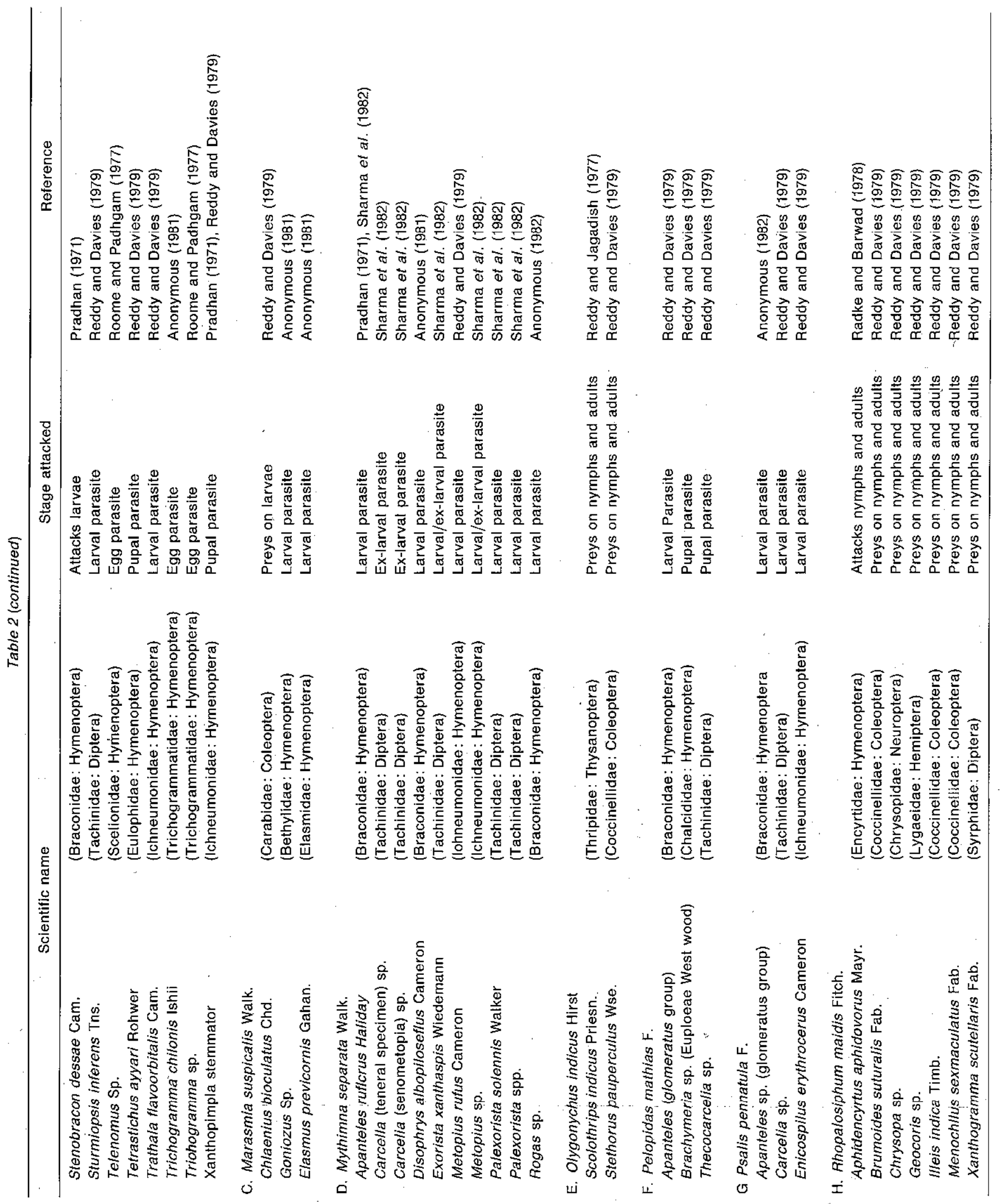




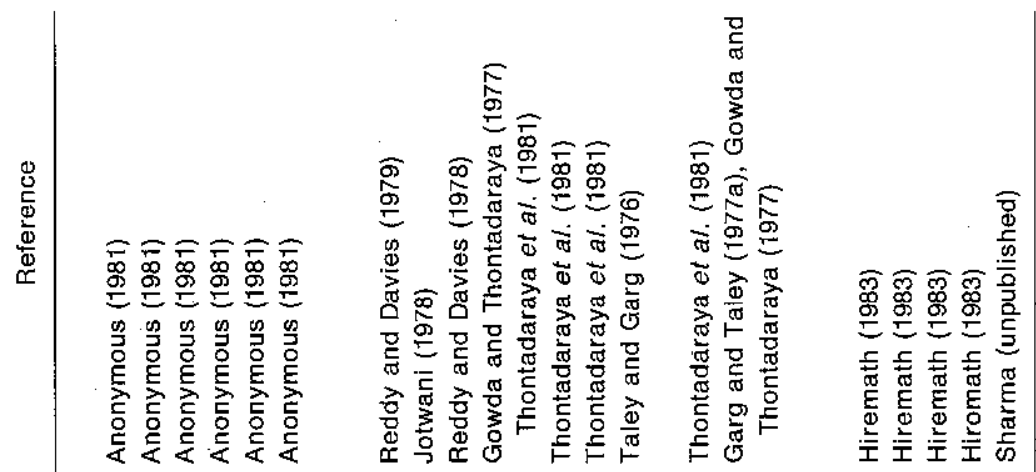

פ⿺辶.

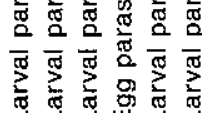

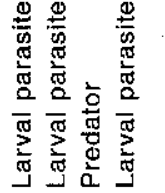

$\frac{\infty}{5} \frac{\infty}{5} \frac{\varphi}{5}$

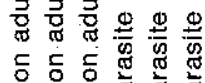

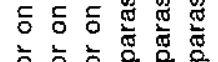

学

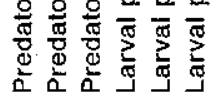

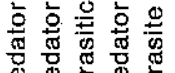

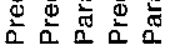
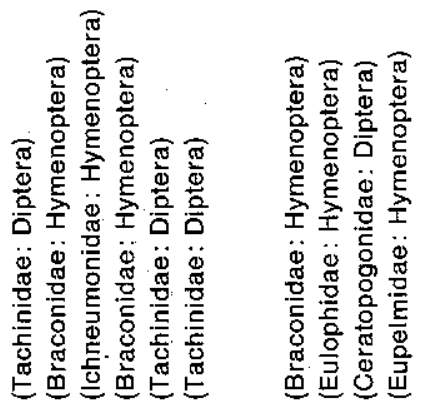

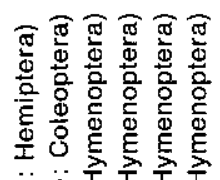

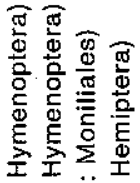

过

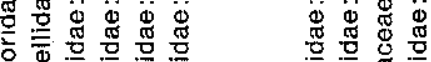

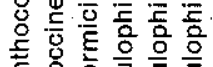

은 을 을

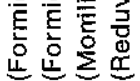

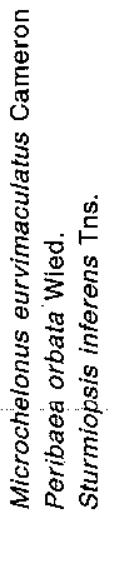

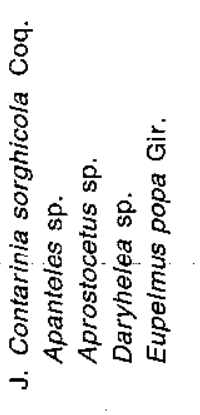
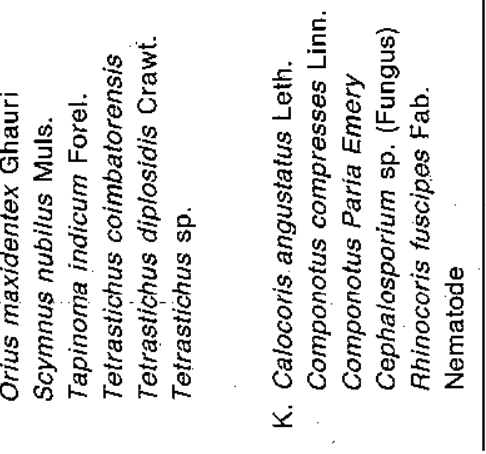


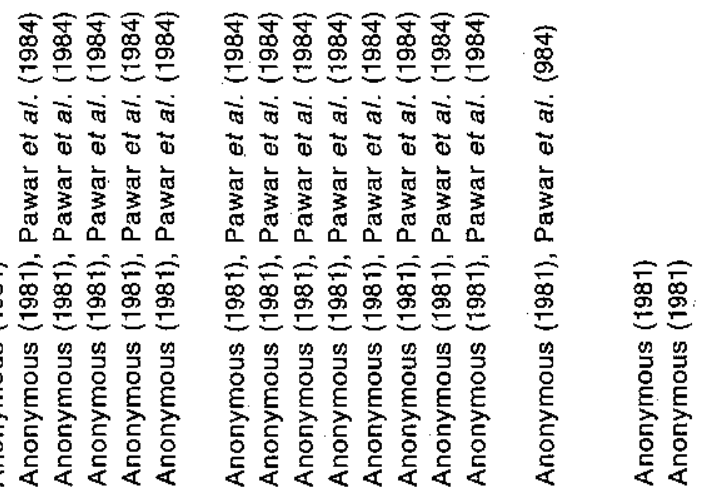

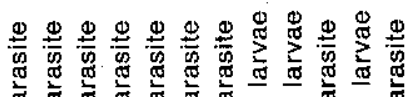

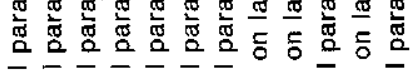

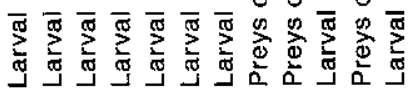

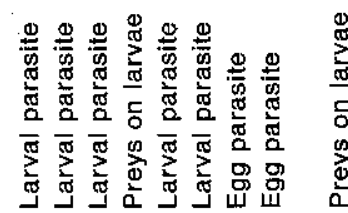

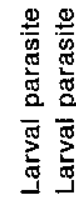
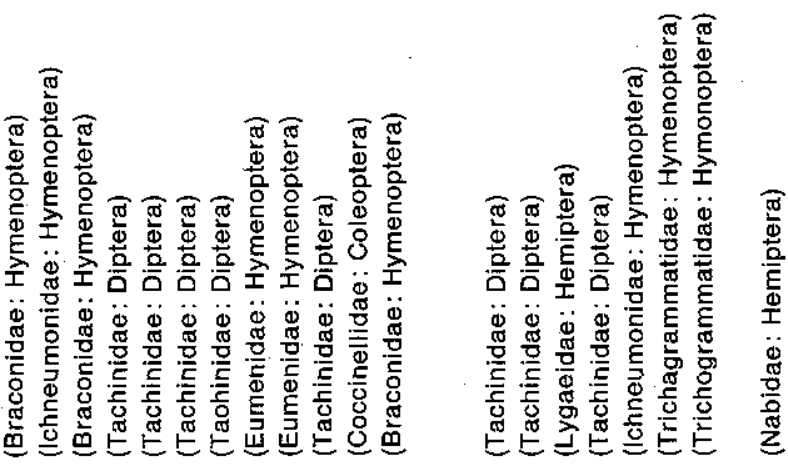

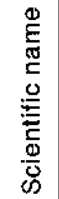

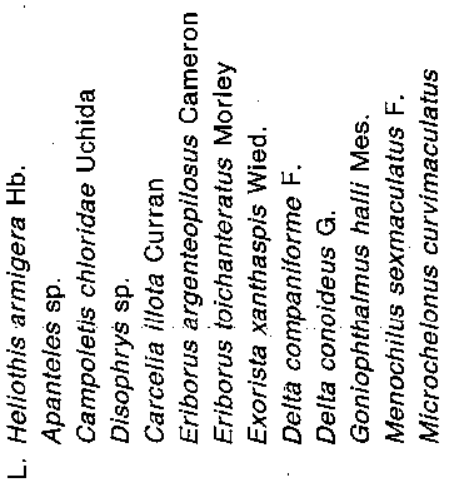

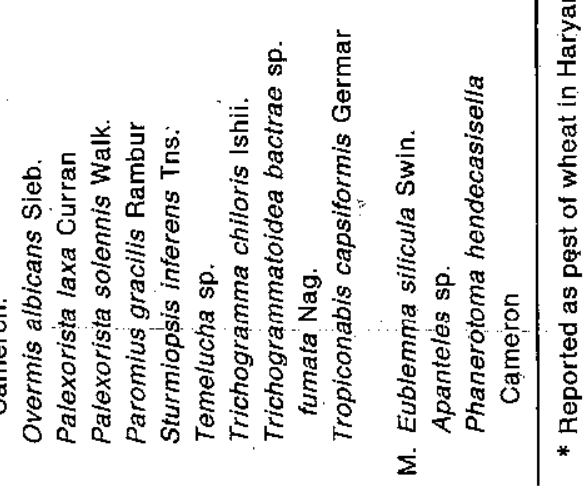


most effective when carefully fitted into systems designed to control specific pests.

Sources of resistance. The search for pest-resistant sorghums began in the mid-1960s. Over the last 20 years, a number of germplasm lines resistant to important insect pests have been identified (Table 3 ). Reasonable levels of resistance to shoot fly, stem borer and midge have been reported. Many of these are currently being utilized in the All India Co-ordinated Sorghum Improvement Project (AICSIP) and the International Crops Research Institute for the Semi-Arid Tropics (ICRISAT) to develop crop varieties with acceptable levels of yield and resistance. The search for resistance against headbugs and head caterpillars has been limited, and so far no sources of resistance have been identified. The loose panicled sorghums, which have long been suspected to be less susceptible to headbugs and head caterpillars, can be completely devoured when they flower during peak infestation periods of these insects. However, they do allow easier access to parasites and predators that may lower insect numbers under normal circumstances.

Host-plant resistance in integrated pest control. Hostplant résistance can be used as a principal component of pest control, an adjunct to cultural, biological, and chemical control and as a check against the release of susceptible cultivars.

Principal control method. Plant resistance to insects was used as the principal control method before the advent of insecticides. In sorghum, this still seems to be the most practical method of keeping pest populations at low levels. A sorghum cultivar, DJ 6514, has been released for cultivation in midge-endemic areas of Karnataka. State for the control of sorghum midge, while $M$ 35-1, which is less susceptible to shoot fly, is widely cultivated in the postrainy season. Resistant cultivers need to be developed for specific pests, areas and regions. Cultivars with adequate levels of resistance can be developed for shoot fly, stem borer, and midge.

The impact of resistant cultivars on insect population ievels can be explained using the simple models of Knipling (1964). The possible effect of growing a moderately resistant cultivar (IS $12664 \mathrm{C}$, half as susceptible as CSH 1) and a highly resistant cultivar (DJ 6514, six times less susceptible than $\mathrm{CSH} 1$ to midge under no-choice conditions) (Sharma et al., 1983) has been demonstrated in Table 4, as a hypothetical example. It is estimated that at the end of the first season, the insect population would be 18 times less on the moderately resistant, and over 1000 times less on the resistant cultivar. During the second year, the insect would be relatively rare on the resistant cultivar. The population on the moderately-resistant cultivar would remain the same but would none the less be several times less than that on the susceptible cultivar. Another advantage in growing a resistant cultivar is that the reduced rate of population increase can prolong the time required to reach economic thresholds (Figure 1).
This is particularly true when there is prolongation of the developmental period and mortality during the immature stages. Further, the economic threshold of a resistant cultivar is much higher than that of a susceptible cultivar.

Although these models may exaggerate the usefuiness of resistant cultivars, they do bring out the tremendous effect the resistant cultivars would have on insect numbers. As we know, the insect population structure will not follow the postulated trend because: (1) it is not possible to plant the same cultivar over large areas, at the same time, (2) the same cultivar will not behave uniformly in space and time, (3) insect populations are highly variable and dynamic in nature and are influenced by many biotic and abiotic factors.

Resistant cultivars and chemical control. The most common form of integrated control involves the use of moderately-resistant cultivars and insecticides. The pest numbers are reduced in each generation and this process slows down the population growth of the insects (Painter, 1951). Even a moderately resistant cultivar in combination with insecticides can bring about a substantial reduction in pest numbers (Table 5). A moderately resistant variety (IS 12664 C) may require insecticide applications in midge endemic areas or years. Assuming that one application of insecticide would reduce insect numbers by $90 \%$, the combined action of the moderately resistant cultivar and the insecticide would produce a 24-fold difference in population between a highly susceptible (CSH 1) and a moderately resistant (IS 12664C) cultivar. Further; it would reduce the population carryover 31 times, and thus result in a substantial reduction in insect numbers in the following year.

Plant resistance may also enhance the effectiveness of the insecticides through better penetration of the insecticides to the target insect through modified plant morphology, e.g. loose earheads would allow better penetration of the insecticides meant to kill headbugs and head caterpiliars and easy access to parasites and predators. Moderate resistance based on imbalanced nutrition or toxic substances may increase the susceptibility of insects to insecticides.

Resistant cultivars and biological control. Resistant cultivars are mostly compatible with biological control. The advantage of using resistant cultivars is that they can help preserve natural enemies through reducing the need to use pesticides. As pointed out earlier, efforts can also be made to identify and breed cultivars that encourage natural enemies.

Resistant cultivars and cultural control. Resistant cultivars can be used in conjunction with cultural control operations. This will have the same effect on the population dynamics of the pest species in question as the combined action of insecticides and resistant cultivars. For example, late planting of $\mathrm{M} 35-1$ during the post-rainy season can substantially reduce shoot fly damage. 


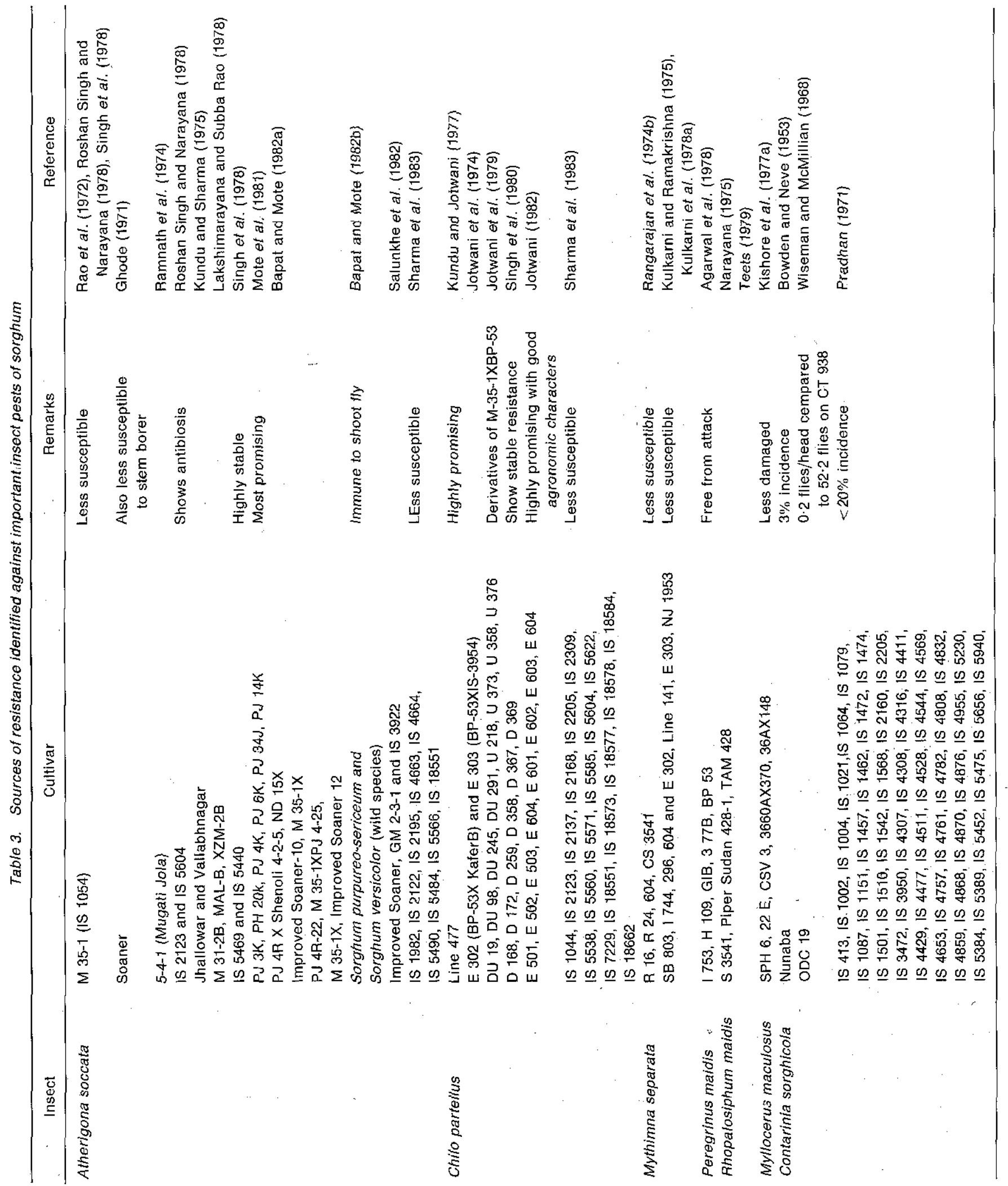




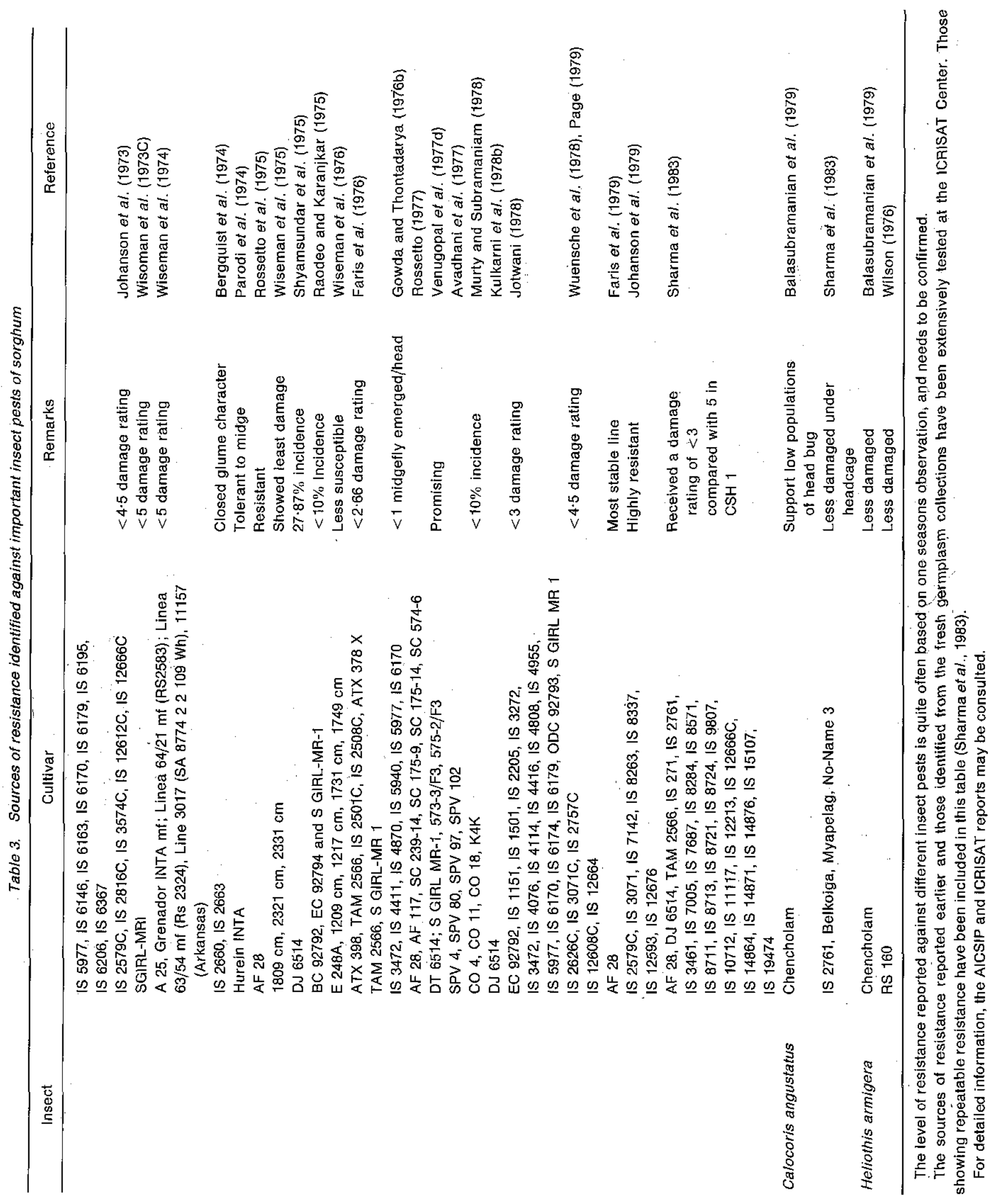


Table 4. Population increase of sorghum midge on $\mathrm{CSH} 7$ (susceptible), is $12664 C$ (moderately resistant) and DJ 6514 (resistant) (a hypothetical example based on Knipling (1964) and Sharma et al. (1983))

\begin{tabular}{|c|c|c|c|}
\hline Generation & $\begin{array}{c}\text { CSH } 1 * \\
\text { (no. of midge } \\
\text { flies/ha) }\end{array}$ & $\begin{array}{c}\text { IS } 12664 C^{*} \\
\text { (no. of midge } \\
\text { flies/ha) }\end{array}$ & $\begin{array}{c}\text { DJ } 6514^{*} \\
\text { (no. of midge } \\
\text { flies/ha) }\end{array}$ \\
\hline \multicolumn{4}{|l|}{ First year } \\
\hline P1 & $100 \dagger$ & $100 *$ & $100^{*}$ \\
\hline$F_{1}$ & 600 & 300 & 100 \\
\hline $\mathrm{F}_{2}$ & 3600 & 900 & 100 \\
\hline$F_{3}$ & 21,600 & 2700 & 100 \\
\hline $\mathrm{F}_{4}$ & 129,600 & 8100 & 100 \\
\hline \multicolumn{4}{|l|}{$\begin{array}{l}\text { Diapause } \\
\text { population }\end{array}$} \\
\hline$(1 \%)$ & 1554 & 120 & 4 \\
\hline \multicolumn{4}{|l|}{ Second year } \\
\hline $\mathrm{P} 2$ & 1554 & 120 & 4 \\
\hline$F_{1}$ & 9324 & 360 & 4 \\
\hline $\mathrm{F}_{2}$ & 55,944 & 1080 & 4 \\
\hline$F_{3}$ & 335,664 & 3240 & 4 \\
\hline $\mathrm{F}_{4}$ & $2,113,984$ & 9720 & 4 \\
\hline $\begin{array}{l}\text { Diapause } \\
\text { population }\end{array}$ & & & \\
\hline$(6 \%):$ & 25,149 & 142 & 1 \\
\hline
\end{tabular}

* Midge population increased six times on $\mathrm{CSH} 1$, three times on IS 12664C, and once on DJ 6514 (Sharma et al., 1983).

$\dagger$ The midge population at the beginning of the season is assumed to be 100 flies/ha.

$\ddagger$ In each generation, $1 \%$ of the total populations is assumed to enter diapause.

$\mathrm{P}$ 1, P2, parent population;

$F_{1}-F_{4}$, no. of insect generations.

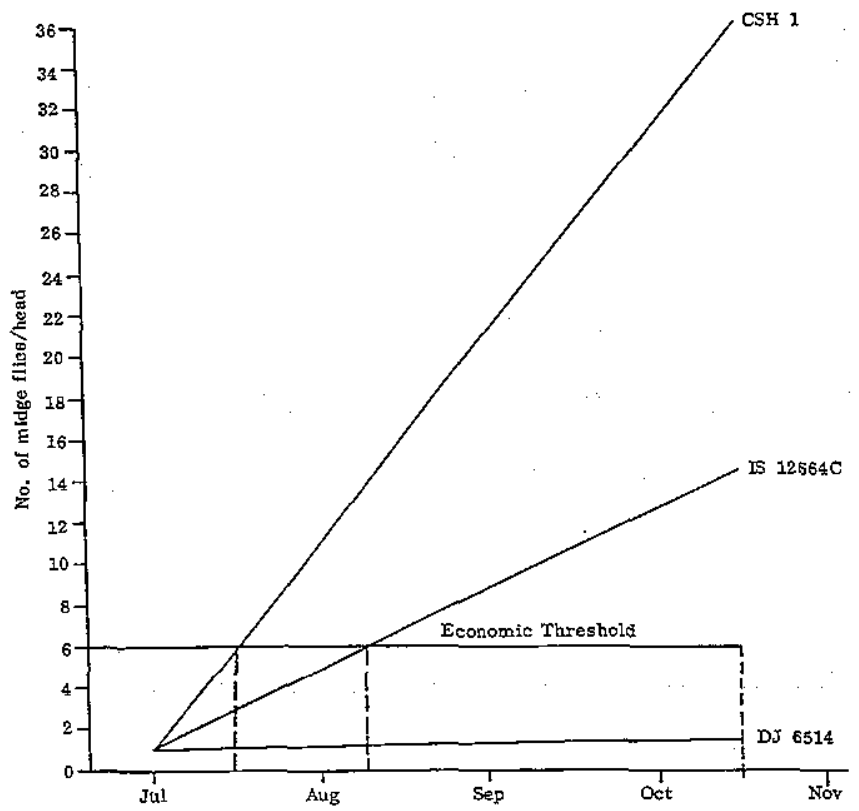

Figure 1. Trends of population increase of sorghum midge on resistant and susceptible cultivars and attainment of economic thresholds (A hypothetical example: the initial midge population is one midge/head (assumed); the midge population multiplies six times on CSH-1, three times on $1 S-12664 C$ and once on DJ-6514

(Tables 4, 5).
Table 5. Population increase of sorghum midge on $\mathrm{CSH} 7$ (susceptible) and IS $12664 \mathrm{C}$ (moderately resistant) plus one insecticidal spray in first generation (a hypothetical example based on Knipling (1964) and Sharma et al. (1983))

\begin{tabular}{|c|c|c|}
\hline Generation & $\begin{array}{c}\text { CSH } 1^{*} \\
\text { (no. of midge } \\
\text { flies/ha) }\end{array}$ & $\begin{array}{c}\text { IS } 12664 C^{*} \\
\text { (no. of midge } \\
\text { flies/ha) }\end{array}$ \\
\hline \multicolumn{3}{|l|}{ First year } \\
\hline P1 & $100 \dagger$ & $100 \dagger$ \\
\hline$F_{1}(+$ insecticide $) \ddagger$ & 60 & 30 \\
\hline $\mathrm{F}_{2}$ & 360 & 90 \\
\hline $\mathrm{F}_{3}$ & 2160 & 270 \\
\hline $\mathrm{F}_{4}$ & 12,960 & 810 \\
\hline Diapause population & 155 & 12 \\
\hline \multicolumn{3}{|l|}{ Second year } \\
\hline $\mathrm{P} 2$ & 155 & 12 \\
\hline$F_{1}(+$ insecticide $) \ddagger$ & 93 & 4 \\
\hline$F_{2}$ & 558 & 12 \\
\hline $\mathrm{F}_{3}$ & 3348 & 36 \\
\hline $\mathrm{F}_{4}$ & 20,088 & 108 \\
\hline Diapause population & 241 & 2 \\
\hline
\end{tabular}

* The population of midge increased six times on CSH 1 and three times on IS 12664 C (Sharma et al., 1983).

it The midge population at the beginning of the season is assumed to be 100 filies/ha.

\$ The insecticide is applied on $F_{1}$ and is presumed to kill $90 \%$ of the population.

$\S$ In each generation $1 \%$ of the total population is assumed to enter diapause.

\section{Chemical control}

Chemical control of pest populations should only be adopted as a last resort but it still remains the main tool in pest management. A number of insecticides have been tested and found effective against important sorghum pests (Table 6, Figure 2). BHC, lindane, carbaryi, carbofuran, malathion and endosulfan can be used effectively to control seedling pests. Dusts, granules, or sprays may be applied, depending on the insect, time and mode of application. Further investigation is required to evaluate the effectiveness of some newer insecticides such as fensulfothion, isophenophos, mephospholan and synthetic pyrethroids against seedling pests. For earhead pests, dusts or sprays of $\mathrm{BHC}$, carbaryl, endosulfan, quinalphos or malathion may be applied at the half-anthesis, post-anthesis or milky stages of the earhead, depending on the pest to be controlled. Care should be taken to use insecticides that are readily biodegradeable and do not leave harmful residues on the grain. Considering the difficulties involved in conventional high volume spraying, dusts, granules and u.l.v. applications may be considered for applying insecticides.

\section{Future strategies for pest control in sorghum}

Pest control programmes should be based on economic thresholds. Economic thresholds and reliable means of monitoring pest populations or damage caused by them need to be established. Shoot fly populations can be monitored using fish meal traps (Figure 3). Populations of stem 
Table 6. Chemical control of important insect pests of sorghum*

\begin{tabular}{|c|c|c|c|c|}
\hline Insect & & Insecticides & & References \\
\hline $\begin{array}{l}\text { Shoot fly, } \\
\text { (Atherigona soccata) }\end{array}$ & $\begin{array}{l}\text { Aldicarb } \\
\mathrm{BHC} \\
\text { Carbaryl } \\
\text { Carbofuran } \\
\text { Diazinon }\end{array}$ & $\begin{array}{l}\text { Dimethoate } \\
\text { Disulfoton } \\
\text { Endosulfan } \\
\text { Fensulfothion } \\
\text { Fenvalerate }\end{array}$ & $\begin{array}{l}\text { Isophenphos } \\
\text { Mephospholan } \\
\text { Methyl demeton } \\
\text { Monocrotophos } \\
\text { Phorate } \\
\text { Phosalone }\end{array}$ & $\begin{array}{l}\text { Singh and Jotwani (1975), Hsieh (1977), } \\
\text { Srivastava and Jotwani (1976a), } \\
\text { Srivastava (1976), Balasubramanian et al. } \\
\text { (1976), Bhimnawawar et al. (1976), } \\
\text { Mote and Pokharkar (1975), Mote and } \\
\text { Talgeri (1975), Srivastava et al: (1973), } \\
\text { Vibhute et al. (1975), Rajasekhara et al. } \\
\text { (1973), Thirumurthi et al. (1973a, b), } \\
\text { Thimmaiah et al. (1973a), Rathore et al. } \\
\text { (1972), Kulkarni et al. (1972), Thobbi } \\
\text { et a/. (1979), Sukhani and Jotwani (1980), } \\
\text { Sadakathulla (1981a), Srivastava et al. (1980), } \\
\text { Sandhu and Dhaliwal (1982), } \\
\text { Mote (1982), Singh and Saha (1969), Baskaran } \\
\text { (1972), Ketkar (1974), Rathore et al (1970), } \\
\text { Mittal et al. (1973), Sandhu and Young } \\
\text { (1974), Jotwani et al. (1971) }\end{array}$ \\
\hline $\begin{array}{l}\text { Stem borer } \\
\text { (Chilo partellus) }\end{array}$ & $\begin{array}{l}\text { BHC } \\
\text { Carbaryi } \\
\text { Carbofuran } \\
\text { Endosulfan }\end{array}$ & $\begin{array}{l}\text { Fenvalerate } \\
\text { Lindane } \\
\text { Malathion } \\
\text { Manocrotophos } \\
\text { Phenoate }\end{array}$ & Quinalphos & $\begin{array}{l}\text { Vaishampayan and Veda (1978), Kishore } \\
\text { and Jotwani (1977), Kundu and Sharma } \\
\text { (1974), Srivastava and Jotwani (1976b), } \\
\text { Srivastava (1976), Bhimanawar et al. } \\
\text { (1976), Vibhute et al. (1975), Venugopal, } \\
\text { et al. (1977b), Kundu and Kishore (1980), } \\
\text { Sadakathulla (1981b), Bhanot et al. (1982), } \\
\text { Manoharan and Balasubramanian (1982), } \\
\text { David et al. (1969), Rathore et al. (1970), } \\
\text { Rangarajan et al. (1973), Agarwal et al. } \\
\text { (1976), Baskaran (1972), Ghode and Katiyar } \\
\text { (1971), Jotwani and Kishore (1973) }\end{array}$ \\
\hline $\begin{array}{l}\text { Armyworm } \\
\text { (Mythimna separata) }\end{array}$ & $\begin{array}{l}\text { BHC } \\
\text { Carbaryi }\end{array}$ & $\begin{array}{l}\text { Dimethoate } \\
\text { Endosulfan }\end{array}$ & Malathion & $\begin{array}{c}\text { Kishore and Jotwani (1976), Bhimanwawar } \\
\text { et al. (1976), Bindra and Rathore (1965) }\end{array}$ \\
\hline $\begin{array}{l}\text { Sorghum-midge } \\
\text { (Contarinia sorghicola) }\end{array}$ & $\begin{array}{l}\text { BHC } \\
\text { Carbaryi } \\
\text { Carbophenathion } \\
\text { Chlorfenvinphos } \\
\text { Diazinon } \\
\text { Dichlorvos } \\
\text { Dimethoate }\end{array}$ & $\begin{array}{l}\text { Disuifoton } \\
\text { Endosulfan } \\
\text { Ethion } \\
\text { Lindane } \\
\text { Fenvalerate } \\
\text { Dimethoate }\end{array}$ & $\begin{array}{l}\text { Malathion } \\
\text { Methamidophos } \\
\text { Methyl-demeton } \\
\text { Methyl-parathion } \\
\text { Monocrotophos } \\
\text { Permathrin } \\
\text { Phenthoate } \\
\text { Phosalone } \\
\text { Quinalphos } \\
\text { Tetrachlorfonvinphos }\end{array}$ & $\begin{array}{l}\text { Rossiter (1977), Carq and Taley. (1977b), } \\
\text { Venugopal et al. (1975, 1977c), Rac (1976), } \\
\text { Deshmukh et al. (1978), Rusas (1970), } \\
\text { Reis et al. (1977), Nunes et al. (1976), } \\
\text { Lara et al. (1976), Deering and Randolph } \\
\text { (1968), Huddlestone et al. (1972), } \\
\text { Borle et al. (1979), Gowda and Thontadaroya } \\
\text { (1976a), MacQuillan et al. (1975), } \\
\text { Thimmaiah et al. (1974), Lara (1974), } \\
\text { Kuishrestha and Singh (1967), Barrow } \\
\text { (1974), Aburto and Castro (1979), } \\
\text { Randolph et al. (1971), Sarkate and Raodeo } \\
\text { (1978), Rocha et al. (1979), Roth and. } \\
\text { Pitre (1973), Stanfords et al. (1972), } \\
\text { Wiseman et al. (1973a,b), Singh et al. } \\
\text { (1979), Radke et al. (1978a,b), Castillo } \\
\text { and Querevedo (1980), Sadakathulla } \\
\text { (1981b), Mogal et al. (1980), Bhanot } \\
\text { et al. (1982), Ward et al. (1972), } \\
\text { Sadakathulla et al. (1978), Coutin (1970) }\end{array}$ \\
\hline $\begin{array}{l}\text { Headbug } \\
\text { (Calocoris angustatus) }\end{array}$ & $\begin{array}{l}\text { BHC } \\
\text { Carbaryi } \\
\text { Carbophenathion } \\
\text { Chlorfenvinphos }\end{array}$ & $\begin{array}{l}\text { Diazinon } \\
\text { Endosulfan } \\
\text { Fenvalerate } \\
\text { Lindane } \\
\text { Malathion }\end{array}$ & Quinalphos & $\begin{array}{l}\text { Rangarajan et al. (1973), Rangarajan } \\
\text { et al. (1974a), Usman (1967), Subba Rao } \\
\text { et al. (1980), Sundararaju et al. (1977), } \\
\text { Kulkarni and Parameshwarappa (1978), } \\
\text { Paul and Srinivasan (1978), David et al. } \\
\text { (1969) }\end{array}$ \\
\hline $\begin{array}{l}\text { Head caterpillars } \\
\text { (Heiiothis armigera) } \\
\text { Eublemma spp. } \\
\text { Cryptoblabes sp. }\end{array}$ & $\begin{array}{l}\text { BHC } \\
\text { Carbaryi } \\
\text { Cypermethrin } \\
\text { Decamethrin }\end{array}$ & $\begin{array}{l}\text { Dichlorvos } \\
\text { Dimethoate } \\
\text { Endosulfan } \\
\text { Fenvalerate }\end{array}$ & $\begin{array}{l}\text { Monocrotophos } \\
\text { Permethrin } \\
\text { Phenthoate } \\
\text { Quinalphos }\end{array}$ & $\begin{array}{l}\text { Kishore and Jotwani (1976), Srivastava } \\
\text { and Singh (1975a,b), Bhonot et al. (1982), } \\
\text { Kishore and Jotwani (1971), Darekar and } \\
\text { Talgeri (1976), Rawat et al. (1970), } \\
\text { Jotwani et al. (1978), Borle et al. (1979), } \\
\text { Kulkarni et al. (1980) }\end{array}$ \\
\hline
\end{tabular}

\footnotetext{
* Based on the published reports between 1965 and 1982.
} 


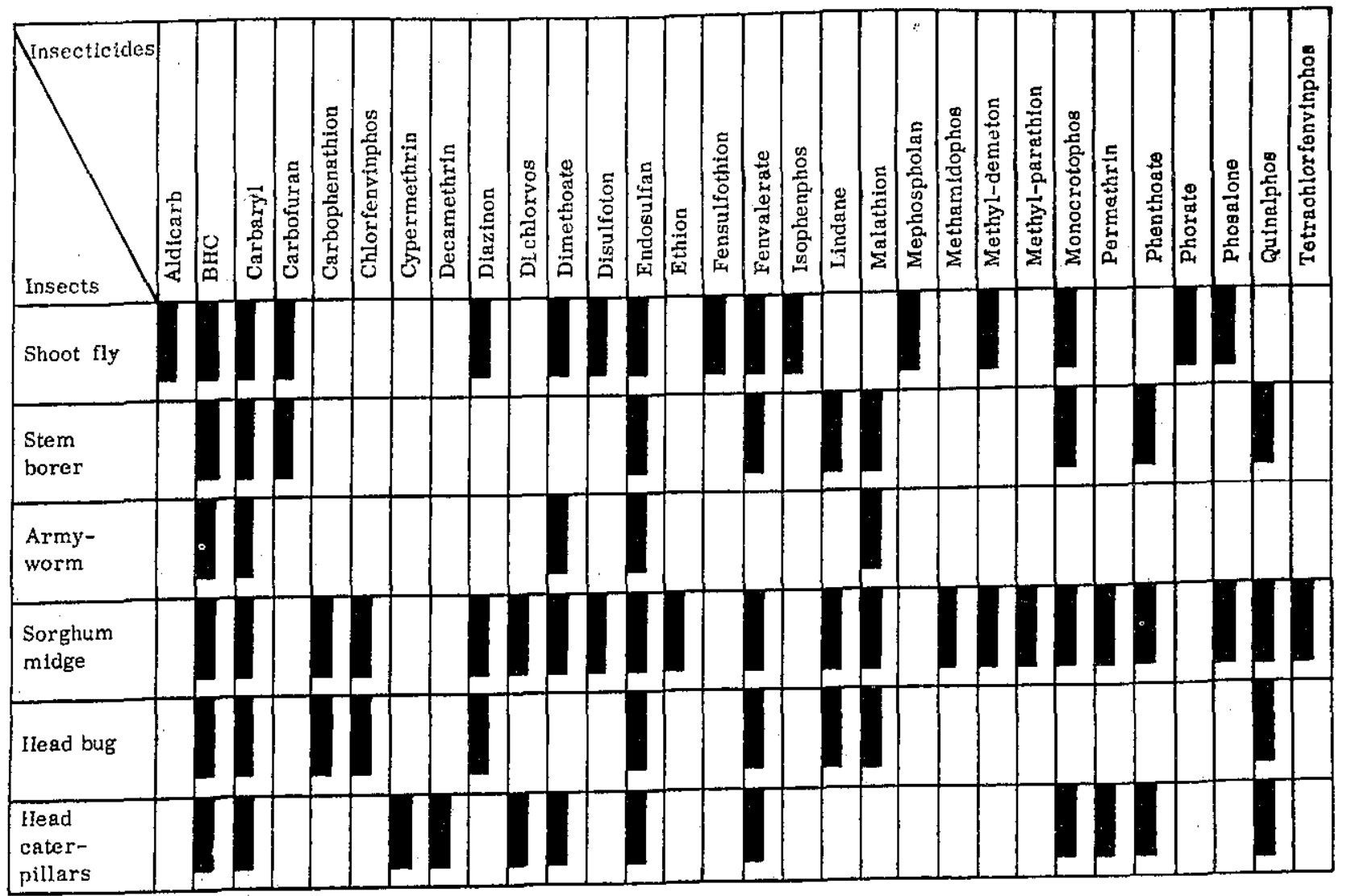

Figure 2. Chemical control of important insect pests of sorghum. $\boldsymbol{\boldsymbol { \Xi }}$, indicates the effectiveness of the insecticide.

borers and Heliothis can be monitored using light and pheromone traps (Figure 4). At present, populations of midge and headbugs (Figure 5) can only be monitored through field surveys. Based on the population dynamics of these pests, sowing dates can be adjusted or insecticides applied to keep the pests in check. Such exercises should be carried out by agricultural universities, research institutes and extension agencies in a particular geo- graphical region, and should be pursued on the lines of operational integrated pest control projects on such crops as cotton and rice. The necessary information can be conveyed to the farmers by radio, television, newspapers or extension agencies.

Cultural pest control operations such as date of sowing, seeding rates, fertilizer application, field sanitation, weeding and cropping systems should form an essential

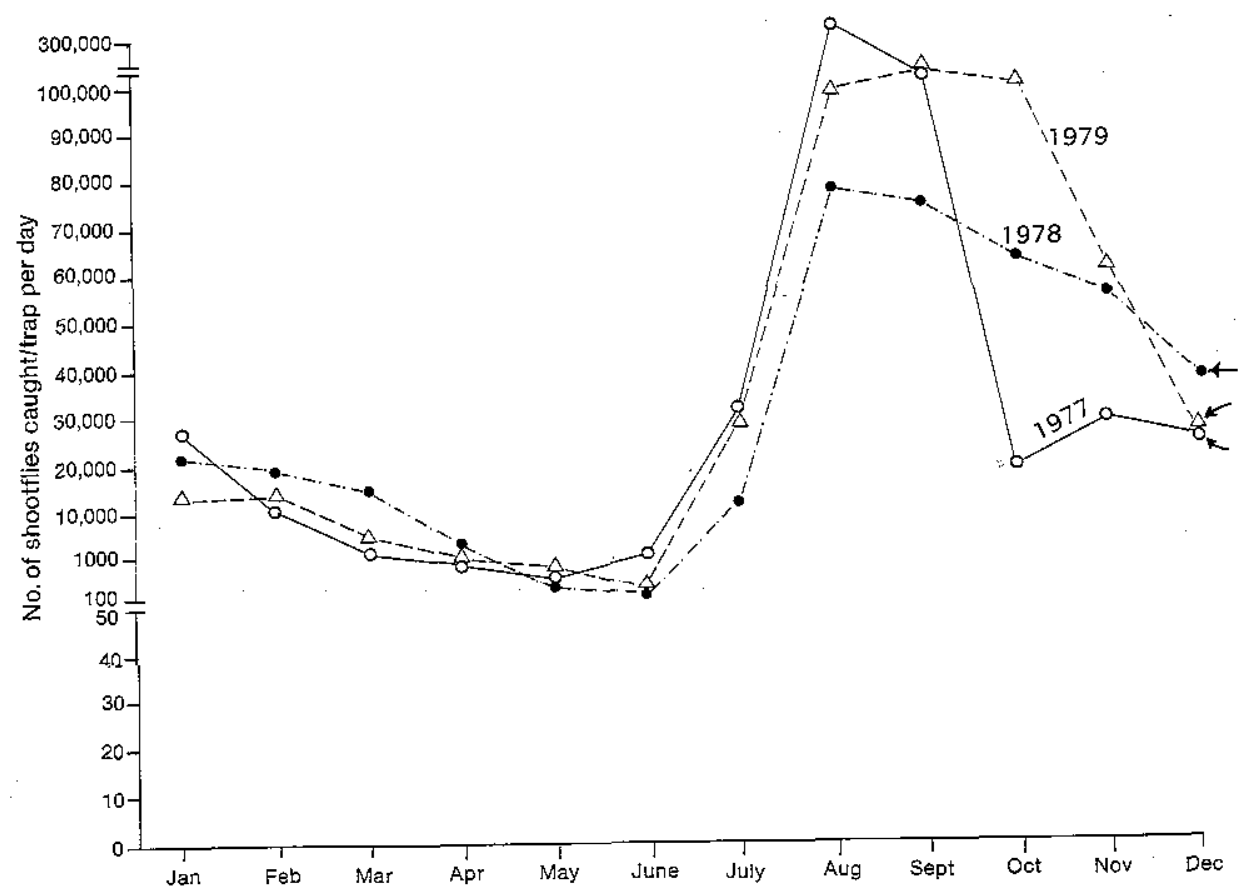

Figure 3. Catches of shootflies in fishmeal traps at /CRISAT Center (1977-79) (Sharma and Davies, 1982). 


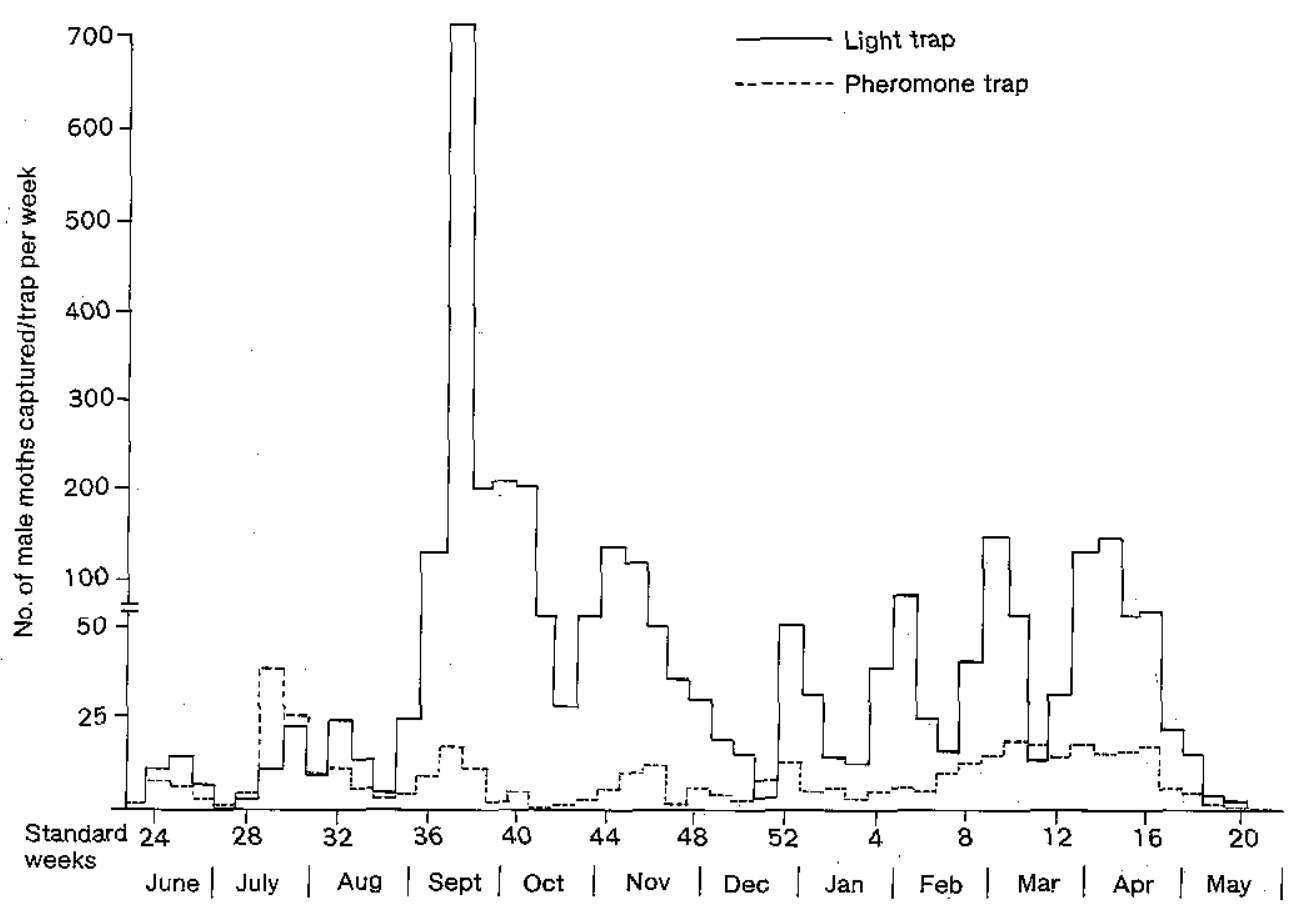

Figure 4. Chilo catches in light and pheromone traps at ICRISAT Center, 1980-81 (ICRISAT, 1982).

component of the pest-management systems. Extension agencies can play a major role in making farmers aware of the benefits of cultural practices for pest control.

The use of pest-resistant cultivars should form the backbone of future pest. management systems. Efforts to develop, release and popularize varieties that are resistant to key pests should be intensified. Several cultivars resistant to midge, shoot fly, and stem borer have been reported (Table 3), and may be recommended for cultivation in endemic areas. Efforts should be made to incorporate resistance into cultivars with good agronomic backgrounds and to strengthen the level of resistance through gene pyramiding. Resistance to headbugs has still not been found. Major emphasis should be placed on such
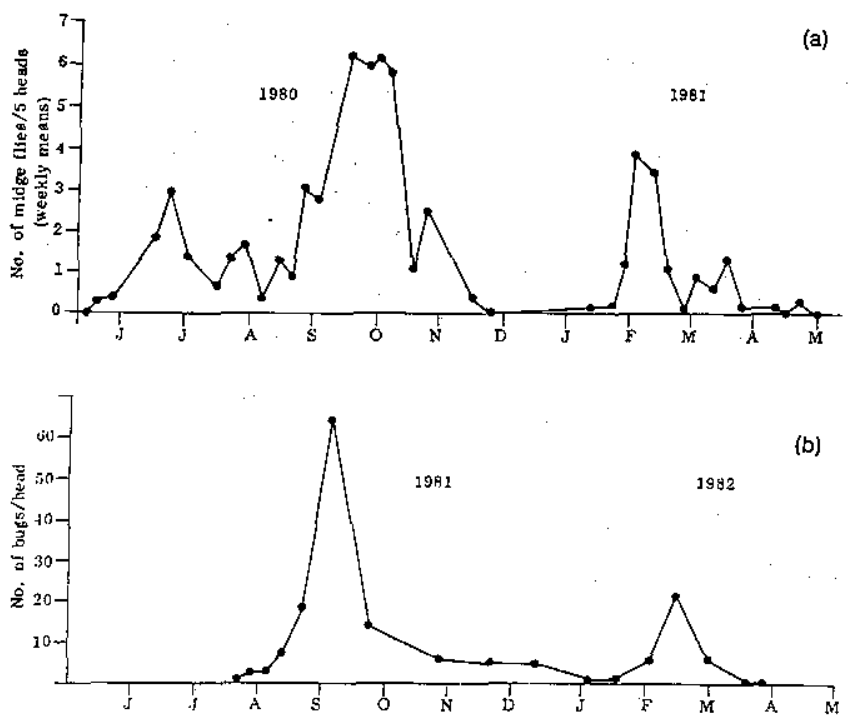

Figure 5. Population dynamics of (a) sorghum midge, Contarinia sorghicola, at ICRISAT Center, 1980-81 (ICRISAT, 1984) and (b) sorghum head bug. Calocoris angustatus, at ICRISAT Center, 1981-82 (ICRISAT, 1984). management practices as sowing date, and the use of cultivars that flower during periods of low bug activity. Loose panicled cultivars need to be developed for areas where headbugs and head caterpillars are major pests. Cultivars resistant to more than one pest need to be developed through 'heterolines' or by combining resistance to different pests through population breeding techniques.

Insecticide effectiveness and selectivity should form the basis of chemical control. Insecticide residues on grain should be determined so that safety intervals can be fixed. Greater emphasis should be placed on the mode of insecticide application. Granules, dusts and u.l.v. applications can easily be substituted for conventional spraying, thus avoiding the difficulties involved in conventional highvolume spraying.

Cropping systems and cultivars that encourage natural enemies should be identified and fitted into pest control schedụles.

The possibility of using attractants, repellants and antifeedants in pest management systems should be explored. Insecticides of plant origin such as those obtained from Azadirachta indica, Acorus calamus, Catharanthus roseus, Bluemea eriantha etc., should be exploited for pest control.

Remote-sensing satellites could be employed to determine host density, location, and extent of damage. Remote sensing can help to detect damage early and determine the effectiveness of control measures. It offers an efficient and cheaper method for pest surveys.

\section{Conclusions}

Insect pest resistant varieties and cultural practices should form the backbone for pest control programs in sorghum agro-ecosystems. Insecticides may be used when necessary based upon economic thresholds. 


\section{Acknowledgements}

I thank Drs L. R. House, K. Leuschner, W. Reed, A. B. Mohamad and S. L. Taneja for their assistance with the preparation of this manuscript.

Approved as Journal Article No. 506 by the International Crops Research Institute for the Semi-Arid Tropics, ICRISAT, Patancheru, P.O. 502 324, A.P., India.

\section{References}

ABURTO, M. S. and CASTRO, I. G., 1979. Study on the control of sorghum midge (Contarinia sorghicola Coq.) in 2 crop seasons. Informe de Investigacion 16, 34-35.

AGARWAL, R. K., VERMA, R. S. and BHARAJ, G. S., 1976. Evaluation of insecticides for the control of jawar stemborer, Chilo partellus Swinhoe. Pesticides 10, 44-45.

AGARWAL, R. K., VERMA, R. S. and BHARAJ, G. S., 1978. Screening of sorghum lines for resistance against shootbug, Peregrinus maidis (Ashmead) (Homoptera: Delphacidae). JNKVV Research Journal 12, 116.

ANONYMOUS, 1981. Arthropod parasites of insect pests (excluding Heliothis spp.) recorded in Andhra Pradesh, India. Progress Report-7, Cropping Systems Entomology. Patancheru, India: International Crops Research Institute for the Semi-Arid Tropics. (Unpublished.)

ANONYMOUS, 1982. Cropping Entomology. Progress Report-8. Patancheru, India: International Crops Research Institute for the Semi-Arid Tropics (Unpublished.)

AVADHANI, K. K., RAMESH, K. V. and KULKARNI, K. A. 1977. A preliminary note on the incidence of sorghum midge (Contarinia sorghicola) at Medium Research Station. Sorghum Newsletter 10, 25.

BALASUBRAMANIAN, G., SIVAPRAKASM, K., KULANDAIVELU, R., and ROBINSON, J. G., 1979. Impact of sorghum earheads on the incidence of earheadbug, caterpillar, webber and mould. Indian journal of Agricultural Research 13, 106-108.

BALASUBRAMANIAN, R., THONTADARAYA, T. S. and HEINRICHS, E. A., 1976. Chemical control of the sorghum shootfly Atherigona soccata Rondani (Diptera: Anthomyiidae) in South India. Mysore Journal of Agricultural Sciences 10, 245251.

BAPAT, D. R. and MOTE, U. N., 1982a. Upgrading the resistance level of derivatives from Indian $X$ Indian crosses of sorghum against shootfly. Journal of the Maharashtra Agricultural Universities 7, 170-173.

BAPAT, D. R. and MOTE, U. N., 1982b. Sources of shootfly resistance in sorghum. Journal of Maharashtra Agricultural Universities 7, 238-240.

BARROW, R. M., 1974. Control of the sorghum midge, Contarinia sorghicola Coq. in Trinidad. pp. 267-274. In Crop Protection in the Caribbean. St Augustine, Trinidad: Department of Crop Science, University of West Indies.

BASKARAN, P., 1972. Efficacy of soil applied insecticides for the control of sorghum shootfly, Atherigona varia soccata (Rondani) and stemborer, Chilo zonellus Swinhoe. Entomologists' Newsletter 2, 17-18.

BERGUIST, R. R., ROTAR, P. and MITCHELLA, W. C., 1974. Midge and anthracnose head blight resistance in sorghum. Tropical Agriculture (Trinidad) 51, 431-435.

BHANOT, J. P., VERMA, A. N. and GREWAL, R. P. S., 1982. Effect of controlling insect pests attacking forage sorghum earheads on grain yield of crop. Haryana Agricultural University Journal of Research 12, 521-522.

BHIMANWAWAR, R. M., GAWANDE, R. B. and BORLE, M. N., 1976. Relative efficacy of some organo-synthetic insecticides against important pests of hybrid sorghum CSH-1, pp. 81-85. In VIII Plant Protection Congress, Moscow, 1975. Reports and Informations. Section III. Chemical Control. Part 1.
BINDRA, O. S. and RATHORE, Y. S., 1965. Chemical control of armyworm (Pseudaletia unipuncta Haw.) on Sorghum vulgare at Jabalpur. Indian Journal of Entomology 27, 222-224.

BLUM, A., 1972. Breeding for insect resistance in crop plants with special reference to sorghum. pp. 398-410. in Sorghum in the Seventies (N. G. P. Rao and L. R. House, Eds). New Delhi, India: Oxford and IBH Publishing Company.

BORLE, M. N., DIOPHODE, S. M. and DESHMUKH, S. D., 1979. Efficacy of some modern synthetic insecticides against some important pests of sorghum. Pesticides 13, 25-26, 31.

BOWDEN, J. and NEVE, R. A., 1953. Sorghum midge and resistant varieties in the Gold Coast. Nature 172, 551.

CASTILLO, P. R. and QUEVEDO, J. S., 1980. Use of pyrethroid insecticides to control sorghum midge and fall armyworm in sorghum. Sorghum Newsietter 23, 106.

CHANNABASAVANNA, G. P., VENKATA RAO, B. V. and RAJAGOPAL, G. K., 1969. Preliminary studies on the effect of incremental levels of phosphatic fertilizer on the incidence of jawar shootfly. Mysore Journal of Agricultural Sciences 3, 253-255.

CHAND, P., SINHA, M. P. and KUMAR, A., 1979. Nitrogen fertilizer reduces shootfly incidence in sorghum. Science and Culture $45,61-62$.

COUTIN, R., 1970. Biology of the sorghum midge (Contarinia sorghicola Coq.) and ehemical control. Phytiatrie Phytopharmacia 19, 65-83.

DAREKAR, K. S. and TALGERI, G. M., 1976. A note on occurrence and control of sorghum webworm (Stenachroia elongella Hmp.) on hybrid sorghum. Indian Journal of Plant Protection 4, 107.

DAVID, V. B., SIVAGAMI, R. and JANAGARAJAN, A., 1969. A schedule for treatment against stemborer and earhead bug; pests of Vellai Cholam. Madras Agricultural Journal 56, 785789.

DAVIES, J. C. and REDDY, K. V. S., 1981. Observations on oviposition of sorghum shootfly, Atherigona soccata Rond. (Diptera: Muscidae). Sorghum Entomology; Progress Report-4. Patancheru, India: International Crops Research Institute for the Semi-Arid Tropics. (Unpublished.)

DESHMUKH, K. S., TALEY, Y. M. and DHURVE, S. B., 1978. A note on the effect of insecticides on sorghum midge and its parasites. Sorghum Newsletter 21, 56-57.

DOERING, G. W. and RANDOLPH, N. M., 1963. Habits and control of the sorghum midge, Contarinia sorghicola on grain sorghum. Journal of Economic Entomology 56, 454-459.

FARIS, M. A., LIRA, Mde A. and VEIGA, A. F. S. L., 1976. Sorghum midge evaluation of the Texas Agricultural Experiment Station International Insect Nursery, Serra Talhada Research Station, Pe, Brazil, 1975. Sorghum Newsiletter 19, 4.

FARIS, M. A., LIRA, Mde A. and VEIGA, A. F. S. L., 1979. Stability of sorghum midge resistance. Crop Science 19, 577-580.

FRANKEL, O. H. and. BENNET, E., 1970. Genetic Resources in Plants: their Exploration and Conservation. Philadelphia: Davis.

GAHUKAR, R. T. and JOTWANI, M. G., 1980. Present status of field pests of sorghum and millets in india. Tropical Pest Management 26, 138-151.

GARG, D. O. and TALEY, Y. M., 1977a. Note on the effect of insecticides on sorghum midge and its parasite Tetrastichus sp. Indian Journal of Agricultural Sciences 47, 313-314.

GARG, D. O. and TALEY, Y. M., 1977b. Chemical control of sorghum earhead midge, Contarinia sorghicola Coquillet. Pesticides 11, 37-38.

GHODE, R. N., 1971. Study of natural resistance of popular sorghum varieties to tissue borers. Sorghum Newsletter 14, 54-56.

GHODE, R. N. and KATIYAR, R. N., 1971. Insecticidal trial to control Chilo partellus (zonellus) Swinhoe. Sorghum Newsletter, 14, 57-58.

GOWDA, B. L. V. and THANTADARAYA, T. S., 1976a. Chemical control of sorghum midge, Contarinia sorghicola (Coquillet) (Diptera: Cecidomyiidae). Current Research 5, 11-13. 
GOWDA, B. L. V. and THONTADARYA, T. S., 1976b. Varietal response of sorghum to the midge, Contarinia sorghicola (Coquillet) (Diptera: Cecidomyiidae). Current Science 4, 177179.

GOWDA, B. L. V. and THONTADARAYA, T. S., 1977. Seasonal incidence of sorghum midge, Contarinia sorghicola (Coquillet) (Cecidomyiidae: Diptera) and its natural enemies. Mysore Journal of Agricultural Sciences 11, 550-554.

HARDAS, M. G., BHAGWAT, V. R. and SHAMAGAT, B. K., 1980. Influence of associate cropping systems on the incidence of sorghum pest complex. College of Agriculture, Nagapur Magazine 51-52, 19-27.

HARDAS, M. G., SUPARE, N. K. and CHOPDE, P. R., 1972. Studies on the seasonal incidence of sorghum midge (Contarinia sorghicola) infesting sorghum hybrids. Sorghum Newsletter 15, 88-89.

HIREMATH, I. G., 1983. Studies on the binomics, crop loss and control of the sorghum earhead bug, Calocoris angustatus Lethierry (Hemiptera: Miridae). Thesis Abstracts 9, 53-54.

$\mathrm{HSIEH}, \mathrm{H}$. L., 1977. Preliminary study on the binomics and control of the sorghum fly. Acta Entomologica Sinica 20, 177-182.

HUDDLESTONE, E. W., ASHDOWN, D., MAUNDER, B., WARD, C. R., WILDE, G. and FOREHAND, C. E., 1972. Biology and control of the sorghum midge. (1) Chemical and cultural control studies in N. Texas. Journal of Economic Entomology 65, 851-855.

ICRISAT (International Crops Research Institute for the Semi-Arid Tropics), 1982. Annual Report 1981. Patancheru, A. P. 502324 , India: ICRISAT.

ICRISAT (International Crops Research Institute for the Semi-Avid Tropics), 1984. Annual Report 1983. Patancheru, A. P. 502324, india: ICRISAT.

JOHNSON, J. W., ROSENOW, D. T. and TEETES, G. L., 1973. Resistance to the sorghum midge in converted exotic sorghum cultivars. Crop Science 13, 754-755.

JOHNSON, J: W., TEETES, G. L., WUENSCHE, A. L. and ROSENOW, D. T., 1979. Sorghum cultivars resistant to the sorghum midge. Sorghum Newsletter 22, 87.

JOTWANI, M. G., 1978. Investigations on insect pests of sorghum and millets with special reference to host plant resistance. Final Technical Report (1972-77). Research Bulletin of the Division of Entomology, Indian Agricultural Research Institute, New Delhi. pp. 114

JOTWANI, M. G., .1982. Factors reducing sorghum yields-Insect pests. pp. 251-255. in Sorghum in the Eighties. Proceedings of the International Symposium on sorghum, 2-7 November 1981. Patancheru, A. P., India: International Crops Research Institute for the Semi-Arid Tropics.

JOTWANI, M. G., ANAND, M. and LAL, R., 1972a. Coccinella undecimpunctata Linn. as a predator of sorghum stemborer Chilo partellus (Swinhoe). Indian Journal of Entomology 34, 70-71.

JOTWANI, M. G. and KISHORE, P., 1973. Control of stemborer Chilo zenellus (Swinhoe) on high yielding sorghum hybrids $\mathrm{CSH} 1$ and $\mathrm{SCH} 3$. Entomologists. Newsletter 3, 51-52.

JOTWANI, M. G., KISHORE, P., SRIVASTAVA, K. P. and SUKHANI, T. R., 1978. Studies on earhead pests of sorghum. Sorghum Newsletter 21, 61

JOTWANI, M. G., KUNDU, G. G., KISHORE, P., SRIVASTAVA, K. P., SUKHANI, T. R. and SINGH, S. P., 1979. Evaluation of some high yielding sorghum derivatives for resistance to stemborer, Chilo partellus (Swinhoe). Indian Journal of Entomology 41, 1-4.

JOTWANI, M. G., MARWAHA, K. K., SRIVASTAVA, K. M. and YOUNG, W. R., 1970. Seasonal incidence of shootfly (Atherigona varia soccata Rond.) in jowar hybrid at Delhi. Indian Journal of Entomology 32, 7-15.

JOTWANI, M. G., SRIVASTAVA, K. P. and KUNDU, G. G., 1974. Two highly promising stemborer resistant lines of sorghum. Entomologists' Newsletter 4, 51-52.

JOTWANI, M. G., SUKHANI, T. R. and SINGH, S., 1971. Seed treatment of sorghum with carbofuran for the control of shootfly. Pesticides 5, 13-14.
JOTWANI, M. G., SUKHANI, T. R. and SINGH, S., 1972b. Population fluctuation and damage of the sorghum midge, Contarinia sorghicola Cocquillet on sorghum crops sown on different dates. Entomologists' Newsletter 2, 50-51.

JOTWANI, M. G. and VERMA, K. K., 1969. Menochilus sexmaculata (Fabricius) as a predator of sorghum stem borer, Chilo zonellus (Swinhoe). Indian Journal of Entomology 31, 84-85.

JOTWANI, M. G., YOUNG, W. R. and TEETES, G. L., 1980. Elements of integrated control of sorghum pests. FAO plant production and protection paper. Rome: FAO. pp. 159.

KETKAR, M. S., 1974. An inexpensive method of shootfly control. Sorghum Newsletter 17, 56 .

KISHORE, P. and JOTWANI, M. G., 1971. Hellothis spp. causing serious damage to sorghum. Entomologists' Newsletter 1' 52.

KISHORE, P. and JOTWANI, M. G., 1976. Chemical control of earhead worms on sorghum. Entomologists' Newsletter 6, 65.

KISHORE, P. and JOTWANi, M. G., 1977. Efficacy of leaf placement of insecticidal dusts against Chilo partellus (Swinhoe). Entomologists' Newsletter 7, 30 .

KISHORE, P., JOTWANI, M. G. and SHARMA, G. C., 1977a. Screening of sorghum lines for relative susceptibility to the cotton grey weevil, Myllocerus maculosus Debrochers (Curculionidae: Coleoptera). Indian Journal of Entómology 39, 379-381.

KISHORE, P., JOTWANI, M. G., SUKHANI, T. P. and SRIVASTAVA, K. P.; 1976. Preliminary studies on the incidence of parasites of sorghum midge, Contarinia sorghicola (Coquillet) at Delhi. Indian Journal of Entomology 38, 200.

KISHORE, P., JOTWANI, M. G., SUKHANI, T. R. and SRIVASTAVA K. P., 1977b. New parasites recorded on the sorghum shootfly, Atherigona soccata Rondani. Current Science 46, 495-496.

KNIPLING, E. F., 1964. The potential role of the sterility method for insect population control with special reference to combining this method with conventional methods. United States Department of Agriculture, Agriculture Research Service 33-98, pp. 54.

KULKARNI,. K. A. and PARAMESWARAPPA, R., 1978. Chemical control of the earhead bug Calocoris angustatus. Sorghum Newsletter 21, 36

KULKKARNI, K. A., PARAMESHWARAPPA, R. and KAJJARI, N. B., 1978a. Screening of high yielding sorghum varieties to armyworm (Mythimna separata Walker). Mysore Journal of Agricultural Sciences 12, 572-574.

KULKARNI, K. A., PARAMESHWARAPPA, R. and KAJJARI, N. B. 1978b. Screening of sorghum entries to midge (Contarinia sorghicola Coquilet). Mysore Journal of Agricultural Sciences 12, 577-578.

KULKARNI, K. A. and RAMAKRISHNA, V. C., 1975. Studies on the susceptibility of sorghum lines and hybrids to the armyworms (Pseudaletia separata Walker). Sorghum Newsletter 17, 46.

KULKARNI, K. A., THIMMAIAH, G. and USMAN, S., 1972. Chemical control of Atherigona varia soccata Rondani. Current Research 2, 110-111.

KULKARNI, K: A., THONTADARAYA, T. S. and JOTWANI, M. G., 1980. Present status of earhead caterpillars on sorghum and their management. Presented at the All India Co-ordinated Sorghum Improvement Project Workshop. 12-14 May 1980, Tamil Nadu Agricultural University, Coimbatore, India

KULSHRESHTHA, J. P. and SINGH, V. S., 1967. Insect pests of hybrid sorghum in U.P: and some methods to control them Labdev Journal of Science and Technology 5, 325-328.

KUNNDU, G. G. and JOTWANI, M. G., 1977, 477-a highly promising stembore resistant line of sorghum. Entomologists' Newsletter 7,7 .

KUNDU, G. G., JOTWANI, M. G. and KISHORE, P., 1978. Efficacy of carbofuran seed treatment for the control of sorghum shootfly at different levels of nitrogen fertilization. Indian Journal of Entomology 40, 346-347.

KUNDU, G. G. and KISHORE, P., 1980. Chemical control of sorghum stemborer, Chilo partel/us (Swinhoe). Indian Journal of Entomology 42, 791-793. 
KUNDU, G. G., KISHORE, P, and JOTWANI, M. G., 1971a. Parasites of Atherigona varia soccata Rondani. Entomologists' Newsletter 1, 14.

KUNDU, G. G., KISHORE, P. and JOTWANI, M. G., 1971b. Host record of Callitula bipartitus Farooqui (MS). Entomologists' Newsletter 1, 20.

KUNDU, G. G. and SHARMA, J. K., 1974. Note on the chemical control of sorghum stemborer. Indian Journal of Agricultural Sciences 44, 902-903.

KUNDU, G. G. and SHARMA, J. K., 1975. Field screening of some local germplasms of sorghum from Rajasthan for resistance against shootfly, Atherigona varia soccata Rondani. Sorghum Newsletter 18, 58-59.

LAKSHMINARAYANA, K., and SUBBA RAO, D. V., 1975. Relative incidence of stemborer in plots with different rates of nitrogen on 148, 302, 926 and CSH-5. Sorghum Newsletter 18, 24-25.

LAKSHMINARAYANA, K. and SUBBA RAO, D. V., 1978. Screening of sorghum varieties for resistance to shootfly. Sorghum Newsletter 18, 22-23.

LARA, F. M., 1974. The influence of genotypes of Sorghum vulgare Pers., locality, time of planting, natural enemies and insecticides on C. sorghicola Coq. Clentifica 1, 118.

LARA, F. M., BUSOLI, A. C. and MARCHIORI, D. L., 1976. Control of Contarinia sorghicola Coq. and phytotoxicity of insecticides in 7 hybrids of Sorghum vulgare (Pers.). Anais da Sociedade Entomologica do Brasil 5, 60-68.

LEU'SCHNER, K. and SHARMA, H. C., 1983. Assessment of losses caused by sorghum panicle pests. In All India Workshop on Crop losses due to insect pests, 7-9 January 1983. APAU, Rajendranagar, A.P., India.

MACQUILLAN, M. J., BADLEY, A. R. and HODGSON, P. J., 1975. Control of sorghum midge with chlorpyriphos in Australia. Journal of Economic Entomology 68, 713-715.

MANOHARAN, T. and BALASUBRAMANIAN, M., 1982. Effect of lindane in controlling the sorghum stemborer, Chilo partellus (Swinhoe) and their persistence in sorghum. Madras Agricultural Journal 69, 33-38.

MITTAL, S. P., RAO, S. B. P., RAMNATH, B., VERMA, B. and SAM, M. S., 1973. Chemical control of shootfly in hybrid sorghum under rainfed conditions. Pesticides 7, 18-19, 25.

MOGAL, B. H., MAIL, A. R., RAJPUT, S. G. and PAWAR, K. L. 1980. Chemical control of sorghum midge (Contarinia sorghicola Coq.). Journal of Maharashtra Agricultural Universities 5, 5-9.

MOTE, U. N., 1982. Efficacy of different formulations of some insecticides against sorghum shootfly. Entomon 7, 265-269.

MOTE, U. N. and POKHARKAR, 1975. Effect of phorate granules-fertilizer mixture and irrigation intervals on the incidence of sorghum shootfly (Atherigona soccata Rondani). Research Journal of Mahatma Phule Agricultural University 6, 71-72.

MOTE, U. N.; SHIROLE, S. M. and BAPAT, D. R., 1981. Screening of local Kharif varieties of sorghum for resistance to shootfly. Journal of Maharashtra Agricultural Universities 6, 165-166.

MOTE, U. N. and TALGERI, G. M., 1975. Effect of placements on efficacy of granulated systemic insecticides against sorghum shootfly (Atherigona varia soccata Rond.). Research Journal of the Mahatma Phule Agricultural University 6, 52-56.

MURTY, A. D. and SUBRAMANIAM, T. R., 1978. Varietal susceptibility of sorghum to the midge (Contarinia sorghicola Coq.). Madras Agricultural Journal 65, 180-182.

NARAYANA, A., 1975. Screening for aphids and sooty molds in sorghum. Sorghum Newsletter 18, 21.

NCEAR, 1967. Pesticides in Indian Agriculture. New Delhi, India: National Council of Applied Economic Research.

NUNES, D., Jr, BARBOSA, J. T. and LARA, F. M., 1976. Phytotoxicity of various insecticides and control of $C$. sorghicola Coq. on the hybrid grain sorghum C-L-120. Cientifica 4, 148-151.

PAGE, F. D., 1979. Resistance to sorghum midge (Contarinia sorghicola Coquillet) in grain sorghum. Australian Journal of Experimental Agriculture and Animal Husbandry 19, 97-101.
PAINTER, R. H., 1951. Insect Resistance in Crop Plants. New York: Macmillan.

PARODI, R. A., GAMBA, R. D. and SCANTAMBURLO, J. L., 1974. "Heurin Inta" grain sorghum variety tolerant to the "Sorghum midge" (Contarinia sorghicola Coq.). Sorghum Newsletter 17, 1.

PAUL, M. D. and SRINIVASAN, S., 1978. Evaluation of certain insecticides for the control of sorghum earhead bugCalocoris angustatus L. Sorghum Newsletter 21, 17-18.

PAWAR, C. S., BHATNAGAR, V. S., and JADHAV, D. R., 1984. Heliothis on sorghum. Presented at the National seminar on pest management on citrus, cotton, sugarcane and sorghum, progress and problems, 5-7 January 1984, Nagpur, India.

PRADHAN, S., 1971. Investigations on insect pests of sorghum and millets. Final Technical Report (7965-70). Division of Entomology, Indian Agricultural Research Institute, New Delhi-12. pp. 157.

PRADHAN, S., 1973. Physiological adaptation and speciation. pp. 11-23. In Insect Physiology and Anatomy (N. C. Pant and S. Ghai, Eds). New Delhi, India: Indian Council of Agricultural Research.

RADKE, S. G. and BARWAD, W. C., 1978. New record of parasite, Aphidencyrtus aphidovorus (Mayr.) (Encyrtidae: Hymenoptera) on Rhopalosiphum maidis (Fitch.) and the efficacy of the various insecticides on the host and effect of parasitism. Indian Journal of Entomology 40, 59-62.

RADKE, S. G., BARWAD, W. L. and BORLE, M. N., 1978a. Effect of various modern insecticides on the emerging and hibernating population of midge fly, Contarinia sorghicola Coq. in $\mathrm{CSH} 1$ earheads. Indian Journal of Entomology 40, 156-164.

RADKE, S. G., BARWAD, W. L. and BORLE, M. N., 1978b. Effect of insecticidal treatments in relation to grain setting in hybrid sorghum CSH 1. Indian Journal of Entomology 40, 165-170.

RAJASHEKARA, B. G., RAGHUNATHA, G., JAGANNATH, M. K. and KRISHNAMURTY, K., 1973. Control of shootfly infesting sorghum. Indian Journal of Entomology 35, 271-273.

RAMNATH, B., VERMA, B., RAO, S. B. P. and MITTAL, S. P., 1974. Effects of dates of planting on sorghum varieties. Sorghum Newsletter 17, 65.

RANDOLPH, N. M., NEISCH, M. V. and TEETES, G. L., 1971. Effectiveness of certain insecticides against the sorghum midge, based on a new method of determining infestations. Journal of Economic Entomology 64, 87-88.

RANGARAJAN, A. V., MAHADEVAN, N. R. and JANAGARAJAN, A:, 1973. Control of stemborer and earheadbug on sorghum K4 Sorghum Newsletter 16, 96-98.

RANGARAJAN, A. V., MAHADEVAN, N. R. and IYEMPARUMAL, S., 1974a. Evaluation of certain dust formulations for the control of the earhead bug and midge on sorghum K4. Sorghum Newsletter 17, 49.

RANGARAJAN, A. V., MAHADEVAN, N. R., KANDASWAMY, G. and IYEMPARUMAL, S., 1974b. Some observations on the susceptibility of sorghum types and hybrids to the cutworm. Pseudaietia unipuncta Haw. Sorghum Newsletter 17, 48.

RAO, M., SINDGI, S. S. and SRINIVASULU, G., 1972. Breeding for shootfly resistance in sorghum. Sorghum Newsletter 13, 32-38.

RAO, S. V. R., 1976. Studies in the biology, binomics and chemical control of the sorghum midge, Contarinia sorghicola Coquillet). Entomologists' Newsietter 6, 14-15.

RAODEO, A. K. and KARANJKAR, R. R., 1975. Screening of sorghum lines for relative damage by the sorghum midge, Contarinia sorghicola (Coq.). Sorghum Newsletter 18, 48-49.

RAODEO, A. K., TIKAR, D. T. and CHUNDURWAR, R. D., 1972. Records of natural parasites of sorghum shootfly, Atherigona varia soccata Rondani. Current Science 41, 430-431.

RATHORE, V. S., RAGHUWANSHI, R. K., SOOD, N. K. and KAUSHIK, U. K., 1970. Control of sorghüm pests. PANS 16, 358-360.

RATHORE, V. S., SOOD, N. K. and RAGHUWANSHI, B. K., 1972. Chemical control of Atherigona varia soccata Rond. 
(Anthomyiidae: Diptera): the sorghum shootfly. Mysore Journal of Agricultural Sciences 6, 471-473.

RAWAT, R. R., JAKHMOLA, S. S. and SAHU, H. R., 1970. Assessment of losses of hybrid sorghum $\mathrm{CSH} 1$ to earhead caterpillars, and comparison of insecticidal controls. PANS 16, 367-369.

REDDY, D. N. R. and JAGADISH, A., 1977. Scolothrips indicus (Thysanoptera: Thripidae) predating upon mites in Bangalore, Karnataka. Acarology Newsletter 5, 7.

REDDY, K. S. and NARASHIMARAO, D. V., 1975. Effect of nitrogen application on shootfly incidence and grain maturity in sorghum. Sorghum Newsletter 18, 23-24.

REDDY, K. V. S. and DAVIES, J. C., 1979. Pests of sorghum and pearl millet and their parasites and predators recorded at ICRISAT Center up to August 1979. Cereal Entomology Progress Report-2. Patancheru, India: International Crops Research Institute for the Semi-Arid Tropics. (Unpublished.)

REIS, P. R., MEIRA, J. L. and BOTELHO, W., 1977. The effect of five insecticides for the control of sorghum midge, Contarinia sorghicola (Coq.) (Diptera, Cecidoyiidae) in 1974/75 and 1975/ 76. Anals da Sociedade Entomologica do Brasil 6, 281-286.

ROCHA, A. D., Da., GRAVENA, S. and MARCONATO, A. R., 1979. Efficiency and phytotoxicity of insecticides for the control of the sorghum midge, Contarinia sorghicola (Coquillet 1898) and the effect on yield. Cientifica 7, 63-67.

ROOME, R. E. and PADGHAM, D. E., 1977. COPR/ICRISAT Collaborative project on sorghum stemborer ecology and behaviour. Report on first study period. Centre for Overseas Pest Research (UK), July-November 1976, pp. 55.

ROSHAN SINGH and NARAYANA, K. L., 1978. Influence of different varieties of sorghum on the biology of sorghum shootfly. Indian Journal of Agricultural Sciences 48, 8-12.

ROSSETTO, C. J., 1977. Types of resistance of sorghum to Contarinia sorghicola. Sorghum Newsletter 20, 5 .

ROSSETTO, $\therefore$ C. J.; BANZATTO, N. V., LARA, J. F. M. and OVERMAN, J. L., 1975. AF-28, A sorghum bicolor variety resistant to sorghum midge, Contarinia sorghicola. Sorghum Newsletter 18, 5.

ROSSITER, P. D., 1977. Insecticides to control sorghum midge, Contarinia sorghicola (Coq.). Queensland Journal of Agricultural and Animal Sciences 34, 147-150.

ROTH, J. R. and PITRE, H. N., 1973. Sorghum midge population dynamics and control. Sorghum News/etter 16, 117-118.

RUSAS, J. E., 1970. Phytoxicity of 9 insecticide formulations applied to 21 sorghum cultivars. Agricultura Tecnica en Mexico 3, 31-35.

SADAKATHULLA, S., 1981a. Efficacy of different new insecticidal formulations in different methods of application for controlling sorghum shootfly, Atherigona soccata.Rond. Pesticides 15, 14-16.

SADAKATHULLA, S., 1981b. Studies on the control of stemborer and grain midge on sorghum. Pesticides 15, 27-29.

SADAKATHULLA, S., MANI, M. and VENUGOPAL, M. S., 1978. Evaluation of efficacy of different spray and dust formulations in the control of the grain midge. Sorghum Newsletter 21 , 69-70.

SALUNKHE, G. N., GANDHALE, D. N., MURTI, T. K. and NAIK, L. M., 1982. Field screening of sorghum lines for resistance to shootfly. Journal of Maharashtra Agricultural Universities 7, 270.

SANDHU, G. S., 1977. New record of predatory beetles on Chilo partellus Swinhoe. Current Science 46, 422.

SANDHU, G. S. and DHALIWAL, G. S., 1982. Control of sorghum shootfly, Atherigona soccata Rond. with insecticidal dusts on sorghum. Entomon 7, 57-61.

SANDU, G. S. and YOUNG, W. R., 1974. Chemical control of sorghum shootfly in India. Pesticides 8, 35-36.

SARKATE, M. B. and RAODEO, A. K., 1978. Studies on the chemical control of sorghum earhead midge, Contarinia sorghicola Cocquillet. Indian Journal of Plant Protection 6, 67-69.

SHARMA, H. C., BHATNAGAR, V. S. and DAVIES, J. C., 1982.
Studies on Mythimna separata at ICRISAT. Sorghum Entomology Progress Report-6. Patancheru, India: International Crops Research Institute for the Semi-Arid Tropics. (Unpublished.)

SHARMA, H. C. and DAVIES, J. C., 1982. Studies on pearl millet insects. Sorghum Entomology Progress Report-7. Patancheru, India: International Crops Research Institute for the Semi-Arid Tropics. (Unpublished.)

SHARMA, H.' C., TANEJA, S. L. and LEUSCHNER, K., 1983. Screening sorghums for resistance to insects. Presented at the All India Coordinated Sorghum Improvement Project Workshop, 19-22 April 1983, HAU, Hissar, India.

SHIVPUJE, P. R., 1977. Record of new natural parasites of sorghum shootfly Atherigona varia soccata Rondani (Diptera: Anthomyiidae) in (ndia. Entomological News 88, 52.

SHYAMSUNDER, J., PARAMESHWARAPPA, R., ANAGARAJA, $\mathrm{H}$. K. and KAJJARI, N. B., 1975. A new genotype in sorghum resistant to midge (Contarinia sorghicola). Sorghum Newsletter 18, 33.

SINGH, K. P., PANDEY, S. Y., SINGH, S., DIVEKAR, V. V. and PARLIKAR, A. B.; 1979. Degradation of carbaryi residues in and on sorghum crop. Journal of Entomological Research 3 182-185.

SiNGH, S. P., JOTWANI, M. G. and RANA, B. S., 1980. Development and stability of sorghum varieties resistant to stemborer, Chilo partellus (Swinhoe). Indian Journal of Entomology 42, 473-481.

SINGH, S. P., JOTWANI, M. G., RANA, B. S. and RAO, N. G. P., 1978. Stability of host plant resistance to sorghum shootfly Atherigona soccata (Rondani). Indian Journal of Entomology 40, 376-383.

SINGH, S. P. and SAHA, H. R., 1969. Chemical control of sorghum shootfly (Atherigona spp.) on Sorghum. PANS 15, 83.

SINGH, V. S. and JOTWANI, M. G., 1975. Control of sorghum shootfly, Atherigona soccata Rond. with phorate and disuifoton granules. Indian Journal of Entomology .37, 219224.

SRIVASTAVA, A. S. and SINGH, Y. P., 1973a. Survey; life history and control of Cryptoblabes gnidiella Mill. (Pyralidae: Lepidoptera), a new pest of hybrid sorghum. Labdev Journal of Science and Technology (B) 11, 37-40.

SRIVASTAVA, A. S. and SINGH, Y. P., 1973b. Control of Heliothis armigera Hub. (Noctuidae: Lepidoptera) attacking sorghum. Current Science 42, 865-867.

SRIVASTAVA, A. S., SINGH, Y. P. and RAM, S., 1973. Control of Atherigona varia soccata Rond. (Anthomyiidae: Diptera), a serious pest of sorghum. Labdev Journal of Science and Technology (B) 11, 17-18.

SRIVASTAVA, K. P., 1976. Chemical control of sorghum pests and studies on persistence of insecticides used on sorghum crop. Entomologists' Newsletter 6, 12-14.

SRIVASTAVA, K. P. and JOTWANI, M. G., 1976a. Efficacy of granular insecticides for the control of shootfly. Entomologists' Newsletter 6, 58-59.

SRIVASTAVA, K. P. and JOTWANI, M. G., 1976b. Efficacy of granular insecticides applied as whorl treatment for the control of sorghum stemborer, Chilo partellus (Swinhoe). Entomologists' Newsletter 6, 50-52.

SRIVASTAVA, K. P., JOTWANI, M. G., AGNIHOTRI, N. P. and JAIN, H. K., 1980. Reiative efficacy of carbofuran formulations and fensulfothion against the shootfly Atherigona soccata (Rondani) and correlation with residues in sorghum plants. Journal of Entomological Research 4, 37-40.

STANFORDS, R. L., HUDDLESTONE, E. W. and WARD, C. R., 1972. Biology and control of the sorghum midge. (3). Importance of stage of bloom and effective residues of selective insecticides. Journal of Economic Entomology 65, 796-799.

SUBBA RAO, D. V., RAO, N. and NARAYANA, K. L., 1980. Evaluation of insecticides as sprays and dusts for the control of sorghum earhead Bug (Calocoris angustatus L.). Sorghum Newsletter 23, 78 . 
SUKHANI, T. R. and JOTWANI, M. G., 1980. Efficacy of newer systemic insecticides for the control of sorghum shootfly, Atherigona soccata Rondani. Indian Journal of Entomology 42, 76-81.

SUNDARAJU, D.; RANGARAJAN, A. V., GANAPATHY, N. and KALAICHELVAN, D., 1977. Control of the earheadbug (Calocoris angustatus L.) on sorghum CSH 5. Sorghum Newsletter 20, 70.

TALEY, Y. M., 1978. A note on the parasites complex of sorghum shootfly, Atherigona soccata Rondani. Presented at the All India Co-ordinated Sorghum Improvement Project Workshop, 17-19 April 1978. University of Agricultural Sciences, College of Agriculture, Dharwad, India.

TALEY, Y. M. and GARG, D. O., 1976. Tapinoma indicum Forel (Formicidae: Hymenoptera) a new predatory ant of Jowar midge, Contarinia sorghicola (Cocidomyiidae Diptera). Cecidologia Indlca 11, 77-79.

TALEY, Y. M. and THAKARE, K. R., 1979. Biology of seven new hymenopterous parasitoides of Atherigona soccata Rondani. Indian Journal of Agricultural Sciences 49, 344-354.

TEETES, G. L., 1979. Overview of pest management and host plant resistance in U.S. sorghum. pp. 181-223. In Biology and Breeding for Resistance to Arthropods and Pathogens in Agricultural Plants. College Station, Texas: Texas $A$ and $M$ University. MP 1451.

THOBBI, V. V., NAIDU, ,M. B. and SINGH, B. U., 1979. Control of sorghum shootfly, Atherigona soccata (Rondani) by systemic insecticides in different types of soils. Indian Journal of Entomology 41, 250-259.

THIMMAIAH, G., DESAI, K. S. M., PANCHABHAVI, K. S. M. and MALIPATIL, M. B., 1972. A note on the effect of late sowing on the incidence of sorghum earhead-bug (Calocoris angustatus Loth.) In North Mysore region. Sorghum Newsletter 15, 34.

THIMMAIAH, G., PANCHABHAVI, K. S., DESAI, K. S. M., USMAN, S. and KAJJARI, N. B., 1973a. Chemical control of sorghum shootfly (Atherigona varia soccata Rondani) (Diptera: Anthomyiidae) in Mysore State. Indian Journal of Agricultural Sciences 43, 294-298.

THIMMAIAH, G., PANCHABHAVI, K. S. and KULKARNi, K. A., 1973b. Seasonal incidence of sorghum shootfly, Atherigona varia soccata Rond. and midge, Contarinia sorghicola Coq. Sorghum Newsletter 16, 69-70.

THIMMAIAH, G., PACHABHAVI, K. S. and KULKARNI, K. A., 1974. Chemical control sorghum midge, Contarinia sorghicola Coquillet. Current Research 3, 82-83.

THIRUMURTHY, S., SUBRAMANIAM, T. R. and PALANISWAMY, P., 1973a. Efficacy of certain new insecticides as seed treatment in the control of sorghum shootfly Atherigona varia soccata Rond, Madras Agricultural Journal 60, 580-581.

THIRUMURTHI, S., SUBRAMANIAM, T. R. and PALANISWAMY, P., 1973b. Evaluation of certain granular insecticides in the control of the sorghum shootfly, Atherigona varia soccata Rond. Madras Agricultural Journal 60, 449-450.

THONTADARAYA, T. S., RAO, K. J. and RANGADHAMAIAH, K., 1981. A brief note on the research work done at the U.A.S. College of Agriculture, Dharwad, on the parasites and predators of the sorghum earhead midge, Contarinia sorghicola (Coq.) during the year 1980-81. Presented at the All india Coordinated Sorghum Improvement Workshop April 1981. Gujarat Agricultural University, Navsari, India.

USMAN, S., 1967. Control of sorghum earheadbug and webbing caterpillar in Mysore. Sorghum Newsletter 10, 57.
VAISHAMPAYAN, S. M. and VEDA, O. P., 1978. Sorghum stem borer, Chilo partellus (Swinhoe) and its control by modern insecticides on hybrid sorghum. Pesticides 12, 19-21, 24.

VENUGOPAL, M. S., MANI, M. and BALASUBRAMANIAN, M., 1977a. Effect of graded doses of phosphorus application on the infestation of sorghum shootfly, Atherigona soccata (Rond.). Madras Agricultural Journal 64, 342-343.

VENUGOPAL, M. S., MANI, M. and BALASUBRAMANIAN, M. 1977b. Comparative toxicity of certain granular insecticides to stemborer, Chilo partellus Swinhoe infesting sorghum. Indian Journal of Plant Protection 5, 148-152.

VENUGOPAL, M. S., MANI, M. and JAYARAJ, S., 1977c. Relative efficacy of some insecticides in the control of sorghum midge, Contarinia sorghicola Coq. Indian Journal of Plant Protection 5, 205-207.

VENUGOPAL, M. S., MANI, M., PALANISWAMY, S. and MEENAKSHI, K., 1977d. Relative resistance of promising sorghum lines to sorghum midge, Contarinia sorghicola Coq. Sorghum Newsletter 20, 68.

VENUGOPAL, M. S., SIVUKUMAR, C. V. and PERUMAL, R. S., 1975. Evaluation of certain insecticides for the control of grain midge, Contarinia sorghicola Coq. on sorghum hybrid $\mathrm{CSH} 1$. Labdev Journal of Science and Technology $B$ (Life Sciences) 13, 179-181.

VIBHUTE, K. S., TALEY, Y. M. and MOREY, G. D., 1975. Chemical contro of sorghum shootfly, Atherigona soccata Rond. and sorghum stemborer, Chilo partellus (=zonellus) Swinhoe on hybrid sorghum $\mathrm{CSH}$ 1. College of Agriculture Nagapur Magazine 1973/74 46, 6-10.

WARD, C. R., HUDDLESTONE, E. W., PARODI, R. A. and RUIZ, G., 1972. Biology and control of the sorghum midge. (2). Chemical Control in Argentina. Journal of Economic Entomology 65, 817-818.

WILSON, A. G. L., 1976. Varietal responses of grain sorghum to infestation by Heliothis armigera. Experimental Agriculture 12, 257-265.

WISEMAN, B. R., FRENCH, J., MCMILLAN, W. W: and TODD, J. W., 1973a. Insecticide treatment to reduce loss in yield of sorghum caused by sorghum insects. Journal of Georgia Entomological Society 8, 123-126.

WISEMAN, B. R. and MCMILLAN, W. W., 1968. Resistance in sorghum to sorghum midge, Contarinia sorghicola (Coquillet) (Diptera: Cecidomyiidae). Journal of the Entomological Society of Georgia 3, 147.

WISEMAN, B. R., MCMILLAN, W. W. and MARCHANT, W. H. 1973b. Control of the sorghum midge. Sorghum Newsletter 16, 113.

WISEMAN, B. R., MCMILLAN, W. W. and WIDSTROM, N. W., 1973c. Registration of SGIRL-MR-1. Sorghum germplasm. Crop Science 13, 398.

WISEMAN, B. R., MCMILLIAN, W. W. and WIDSTROM, N. W.; 1974. International sorghum midge evaluations. Sorghum Newsletter 17, 80.

WISEMAN, B. R., MCMILLIAN, W. W. and WIDSTROM, N. W., 1975 Screening for sorghum midge resistance. Sorghum Newsletter 18, 79-80.

WISEMAN, B. R., McMILLIAN, W. W. and WIDSTROM, N. W., 1976. Screening for sorghum midge resistance, 1975. Sorghum Newsletter 19, 102.

WUENSCHE, A. L., TEETES, G. L., JOHNSON, J. W., PHILLIPS, J. M. and LUZA, T.W., 1978. Studies of sorghum midge resistant sorghums in progress at Texas $A$ and $M$ University. Sorghum Newsletter 21, 107-108. 